DOI: $10.1111 /$ jmcb. 12740

\author{
JOHANNES BUBECK \\ ANGELA MADDALONI \\ JOSÉ-LUIS PEYDRÓ
}

\title{
Negative Monetary Policy Rates and Systemic Banks' Risk-Taking: Evidence from the Euro Area Securities Register
}

\begin{abstract}
We show that negative monetary policy rates induce systemic banks to reachfor-yield. For identification, we exploit the introduction of negative deposit rates by the European Central Bank in June 2014 and a novel securities register for the 26 largest euro area banking groups. Banks with more customer deposits are negatively affected by negative rates, as they do not pass negative rates to retail customers, in turn investing more in securities, especially in those yielding higher returns. Effects are stronger for less capitalized banks, private-sector (financial and nonfinancial) securities and dollar-denominated securities. Affected banks also take higher risk in loans.
\end{abstract}

JEL codes: E43, E52, E58, G01, G21

Keywords: negative rates, nonstandard monetary policy, reach-for-yield,

securities, banks

\begin{abstract}
We thank Raj Iyer for providing valuable suggestions in the early stage of this project. We also thank our discussants Ugo Albertazzi, Thorsten Beck, Matteo Crosignani, Mathias Kronlund, and Skander van den Heuvel, as well as an anonymous referee and the editor Robert DeYoung for useful comments and suggestions. We also thank the participants at EFA 2020, FIRS 2019 in Savannah (Georgia), the CEMFI/Banco de España Second Conference on Financial Stability in Madrid, the 50th Anniversary Conference of the JMCB in Frankfurt, the Eight Italian Congress of Econometrics and Empirical Economics in Lecce, the Second Conference of the ESCB Research Cluster 3 on Financial Stability, and seminars at the University of Mannheim, BIS, ECB, Deutsche Bundesbank, and the Federal Reserve Bank of New York. Valerio Morelli and Niklas Grimm provided excellent research assistance. This project has received funding from the European Research Council (ERC) under the European Union's Horizon 2020 research and innovation programme (grant agreement No 648398). Peydró also acknowledges financial support from the PGC2018-102133-B-I00 (MCIU/AEI/FEDER, UE) grant and the Spanish Ministry of Economy and Competitiveness, through the Severo Ochoa Programme for Centres of Excellence in R\&D (SEV-2015-0563). The views expressed do not necessarily reflect those of the European Central Bank, Deutsche Bundesbank, or the Eurosystem.
\end{abstract}

JoHAnnes Bubeckis at Deutsche Bundesbank (E-mail: johannes.bubeck@bundesbank.de). ANGELA MAdDALONiis at European Central Bank (E-mail: angela.maddaloni@ecb.europa.eu). JosÉ-LuIS PEYDRóis at Imperial College London, ICREA-Universitat Pompeu Fabra, CREI, Barcelona GSE, and CEPR (E-mail: jose.peydro@gmail.com).

Received January 24, 2019; and accepted in revised form February 11, 2020.

Journal of Money, Credit and Banking, Supplement to Vol. 52, No. S1 (October 2020) (C) 2020 The Ohio State University 
CENTRAL BANKS HAVE IMPLEMENTED a series of unconventional monetary policies during the last decade. An important difference in the implementation of monetary policy between the euro area and the United States has been the use of negative policy rates (NPRs). The Federal Reserve in particular (and also the Bank of England) has been somewhat critical of the use of negative rates (see Bernanke 2016). In the euro area, however, negative policy rates were introduced by the European Central Bank (ECB) in June 2014, when the deposit rate for banks with an account at the central bank was lowered to -10 basis points. Negative rates have also been introduced by central banks in several other countries (Japan, Denmark, Sweden, and Switzerland), and the value of securities (bonds) yielding negative rates reached around 15 trillion U.S. dollars (USD) as of July 2019. ${ }^{1}$ Therefore, negative rates currently represent an important policy tool, which going forward may be considered part of the standard toolkit, especially given the secular low levels of rates around the world. Thus, a key question is what are the effects of negative policy rates for banks?

In this paper, we analyze the impact of negative monetary policy rates on reachfor-yield behavior by banks. For identification, we exploit the introduction of negative deposit rates by the ECB in June 2014 and a novel securities register for the 26 largest euro area banking groups. Banks with more customer deposits tend to be more negatively affected by negative rates, as it is more difficult to pass negative rates to their retail customers. ${ }^{2}$ In sum, our results show that, after the introduction of negative rates, banks with higher (as compared to lower) ex ante customer deposits invest relatively more in securities, especially in those securities yielding higher returns. Reach-for-yield effects through this deposit channel are stronger for less capitalized banks. Moreover, we find that more affected banks also take higher risk in loans.

The transmission of monetary policy at the "zero lower bound" and below has become a topic of particular interest for researchers and policymakers since several central banks have chosen this path in the last few years (Brunnermeier and Koby 2018, Eisenschmidt and Smets 2018). A very recent literature is assessing how negative policy rates are transmitted through the banking sector and how they affect credit supply to the economy and the equity valuations of banks (see, e.g., Ampudia and Van den Heuvel 2018, Basten and Mariathasan 2018, Bottero et al. 2019, Heider, Saidi, and Schepens 2019, Eggertsson et al. 2019). However, to the best of our knowledge, ours is the first paper to analyze how negative policy rates affect investment choices in the securities portfolios of banks.

Analyzing banks' reach-for-yield in securities is important for several reasons. First, securities holdings represent an important share of the assets held by banks around the world: For example, in Europe they account for around 20\% of total banking assets. In part because of lack of detailed micro data, banks' securities

1. See, for example, https://www.bloomberg.com/news/articles/2019-08-06/negative-yielding-debthits-record-15-trillion-on-trade-woes.

2. In this paper, we refer to customer deposits or retail deposits (or simply deposits) as the same concept (see Section 1). 
portfolios have not been analyzed as much as credit. While credit register data are available for several countries (in Europe, Asia, the Americas, and even Africa), the new data set at our disposal, which provides detailed information on securities holdings at the bank and security (the International Securities Identification Number [ISIN]) level is not generally available for other regions in the world. For each security, we have information on yield, issuer, ratings, price, and remaining maturity. In particular we observe, even within the same issuer (like a sovereign), all the different securities with different yields and maturities held by each bank in a certain quarter. The overall nominal holdings in our database are valued at around 3 trillion euros.

Second, banks take risk through their securities holdings in addition to their lending portfolios. In Europe, for example, during the sovereign debt crisis, the soundness of banks in some countries was severely affected by the decrease in prices of sovereign bonds held in their portfolios, which represented a strong link between the stability of the banking sector and of the sovereigns issuing the securities-the socalled sovereign-bank nexus (Acharya and Steffen 2015, Brunnermeier et al. 2016). As banks may take significant risk via securities holdings, policymakers have discussed how to regulate the investment of banks in securities, which is at the center of an important policy debate. In Europe, the Liikanen and the Vickers Reports addressed these issues and in the United States the Volcker Rule in the Dodd-Frank Act. Finally, securities are more liquid than loans and bank risk can be more easily reallocated by changing the positions in liquid assets (Myers and Rajan 1998). ${ }^{3}$

How are negative rates transmitted through the banking sector and affect bank risktaking? A reduction in the policy rate transmits to short-term rates first. Since banks tend to have long-term assets and shorter-term liabilities on their balance sheets, a rate cut should result in an increase in bank net worth via banks passing-through the rate cut on their liability side. However, the pass-through of negative rates is somewhat different: banks do not generally pass on negative rates to their retail depositors, differently from their wholesale deposits. As we discuss below, these funding structures tend to be persistent and high retail deposit banks have less wholesale deposits than low deposits banks, which implies that they are overall less able to pass the negative rates to their liabilities. Evidence from our sample of banks, and in related work (see Altavilla et al. 2019), also suggest that these high retail deposit banks are not increasing fees more than other banks on average.

When interest rates are positive, the impact of a cut in policy rates on bank risktaking is theoretically ambiguous (see Dell'Ariccia, Laeven, and Marquez 2014, Dell'Ariccia, Laeven, and Suarez 2017). There are at least two different forces at work. First, a portfolio reallocation effect—safe assets become less attractive, which induces banks to take more risk. Second, a risk-shifting effect-lower interest rates increase franchise value, which would induce less risk-taking. The net effects of these

3. Myers and Rajan (1998) allude to the concept of transformation risk. They argue that "greater asset liquidity reduces the firm's ability to commit to a specific course of action" and hence "managers could substitute risky assets for safe ones"- or the other way around. Some recent evidence provided by Timmer (2018) shows indeed that banks react strongly to past returns in the securities holdings and adjust their holdings accordingly, leading to procyclicality in investment dynamics. 
two factors depend on banks' ability to pass-through rates to customers and to change their capital structure. Negative rates induce a differential shock across banks with different retail deposit ratios (see also Brunnermeier and Koby 2018, Eggertsson et al. 2019). For these banks (as compared to banks with higher funding from the wholesale market), negative rates represent a financial burden, decreasing their franchise value and hence inducing overall more risk-taking.

To test this theoretical prediction, we use a difference-in-differences specification where we analyze how the holdings of a particular security change in response to the introduction of negative policy rates, differentiating between high (retail) deposit ratio and low deposit ratio banks. As argued above, banks with different retail deposit ratios are affected differently when policy rates reach negative territory and this provides a way to identify the effects of negative policy rates on reach-for-yield in securities from other forces that shape both monetary policy and the investment behavior of large euro area banks.

We exploit the data on securities holdings in Q4 2013-Q1 2014 for the pre-NPR period and Q2 2014-Q4 2014 for the post-NPR period. We end our analysis in Q4 2014, excluding the following period when the ECB announced and then implemented the expanded Asset Purchase Programme (APP), that is, the euro area quantitative easing (QE). We analyze the data at the security-bank-quarter level. This allows us to: (i) test whether the change in securities induced by the introduction of negative policy rates differs with certain (observed) bank characteristics controlling for unobserved bank heterogeneity; (ii) control for unobserved security characteristics (e.g., the issuance of a particular security) via security (or other related) fixed effects; and (iii) identify reach-for-yield, in particular whether banks with different characteristics (deposit ratio) change their holdings of securities with different yields. We analyze the data in a panel comparing the period before and after the introduction of negative policy rates. In addition, we analyze the results quarter by quarter to check the parallel trend assumption.

We find robust evidence that negative policy rates lead to reach-for-yield behavior in the securities holdings of more exposed banks. Comparing the period before and after the introduction of negative rates, we show that banks more reliant ex ante on customer deposits (compared to the other banks) relatively increase their holdings of securities, with stronger effects for those securities yielding higher returns. ${ }^{4}$ Results are robust to controlling for security risk characteristics, like maturity and ratings, which are the main determinants of capital regulation, security fixed effects, or unobserved bank heterogeneity via bank fixed effects. Effects are also similar if we estimate weighted regressions (by weighting each security by the overall holding amount) or if we control for the covariance between a security and the current bank portfolio. We find no evidence of a similar relationship in the period before the introduction of negative rates. Before the introduction of negative rates, the response

4. We do not find evidence that more affected banks increase or decrease overall lending, but they increase their securities holdings. There are also somewhat higher deposit inflows to these more affected banks after the introduction of negative rates (see discussion at the end of Section 2.1). 
of banks' holdings to changes in yields of securities does not differ for banks with different levels of deposit ratio. Overall, the economic effects are significant: after the introduction of negative rates, a difference in the deposit ratio of 10 percentage points (approximately one standard deviation) would imply an around 2 percentage points increase in the sensitivity of holdings of a particular security in response to a 1 percentage point change in the adjusted current yield (ACY). ${ }^{5}$

We then analyze how more affected banks take higher risk. The analysis within different asset classes shows that the reach-for-yield effects are confined to holdings of debt securities issued by private firms, both financial and nonfinancial corporations. Effects are not economically and statistically significant for public debt (for asset-backed securities [ABS], estimated effects are large, though the standard errors increase substantially for this asset class). As regards to currency, the more affected banks reshuffle their portfolios toward riskier securities denominated in U.S. dollar in addition to euro currency - this is relevant when considering international spillovers of euro area monetary policy. ${ }^{6}$ Moreover, in terms of duration risk, we show that more affected banks reshuffle their portfolios more toward longer-term higher-yielding securities. Importantly, the reach-for-yield effects by high-deposit banks are stronger for weakly capitalized banks, consistent with risk-shifting. Finally, our results suggest that more affected banks also increase their risk in loans. Therefore, we overall provide evidence that negative rates induce large, systemic banks to take on higher risk in both securities and loans. ${ }^{7}$

Contribution and related literature. Our main contribution is to the growing literature on the impact of nonstandard monetary policy measures. ${ }^{8}$ Despite a substantial number of empirical studies addressing the impact of quantitative easing, lending policies by central banks (such as the longer-term refinancing operations [LTROs] and targeted longer-term refinancing operations [TLTROs] implemented by the ECB) and forward guidance, there is less evidence on negative rates, which is a more unique and special policy. To the best of our knowledge, this is the first paper to show how negative policy rates affect the securities holdings of banks for a large set of multinational, systemic banks.

Ampudia and Van den Heuvel (2018) look at the effects of ECB monetary policy announcements on bank equity including periods of low and negative interest rates. They find that when interest rates are positive, an unexpected decrease in policy rates raises bank equity—as in English, Van den Heuvel, and Zakrajšek (2018). However, when policy rates are zero or negative, the impact can be reversed-in particular for banks that rely more on deposit funding — and further rate cuts lower bank equity, a

5. This statement is based on the third column of Table 4 .

6. See, for example, Obstfeld (2019), Morais et al. (2019), or Rajan's complain on U.S. QE as RBI governor in a 2014 interview with Bloomberg (https://www.bloomberg.com/news/articles/2014-01-31/ india-vs-dot-the-u-dot-s-dot-when-central-bankers-collide).

7. Note, however, that banks with higher ex ante retail deposits only increase overall securities holdings, not overall credit, after the introduction of NPR, see in particular Table A3.

8. We also contribute to the literature on the risk-taking channel of monetary policy, see for example, Maddaloni and Peydró (2011) and the references therein. 
result consistent in spirit with the notion of a reversal rate as in Brunnermeier and Koby (2018). Altavilla, Boucinha, and Peydró (2018) analyze the impact of standard and nonstandard monetary policy on bank profitability. They find that a monetary policy easing (a decrease in short-term interest rates and/or a flattening of the yield curve) is not associated with lower bank profits when controlling for the endogeneity of the policy measures to expected macroeconomic and financial conditions, though accommodative monetary conditions asymmetrically affect the main components of bank profitability. Differently to these papers, we analyze security-level data.

Our results are complementary to the results found by Heider, Saidi, and Schepens (2019). We broadly share their identification strategy, based on the banks' reliance on customer deposits. They analyze the risk profile of the syndicated loan portfolios of banks during the period of the introduction of negative interest rates. They find that banks with more deposits tend to lend less overall but more to riskier borrowers. Using a similar strategy with Swiss data, Schelling and Towbin (2018) find that banks with a lot of deposits offer more generous lending terms in order to capture market shares. We provide complementary evidence to these studies based on the analysis of the securities holdings of banks. In the last part of the paper, we also run a robustness analysis using syndicated lending data for the banks in our sample, and we find evidence of reach-for-yield in both securities and loans for the largest euro banks, which are the most systemically relevant.

Other studies on the impact of negative rates have relied on banks' excess reserves at the central bank. Demiralp, Eisenschmidt, and Vlassopoulos (2017) assess the impact of negative policy rates on lending volumes and holdings of government bonds. Their identification strategy is based on banks' excess liquidity deposited at the ECB. They find that more exposed banks increase their overall holdings of nondomestic government bonds. Their data set does not have the granularity to control for risk or issuance at the security level nor the exhaustive analysis of heterogeneous effects across different securities with different yield levels (i.e., we exploit a securities register). In our sample, where we can distinguish different securities (with different yields and maturities) issued by the same sovereign, we do not find evidence of reach-for-yield within sovereign bonds. Using a similar identification strategycentral bank reserves at the Swiss National Bank-Basten and Mariathasan (2018) show in a bank-level analysis that, in aggregate, more affected banks are lending more and invest more in financial assets. Our channel of identification and also data are different.

Our paper is also related to Peydró, Polo, and Sette (2017). Using the Italian securities register during the recent crisis period, but before the introduction of negative rates, they show that bank risk-taking in response to a monetary policy loosening is proportional to a particular bank's risk-bearing capacity (i.e., bank capital) - a result inconsistent with the risk-shifting hypothesis which would apply to banks with low levels of capital (gambling for resurrection). We show that in our sample this result also holds: after NPR introduction, banks with higher capital reach for higher yield. However, among the most affected banks (i.e., banks with high deposit ratios), those 
with higher equity take less risk after NPR introduction. In the most recent period, Bottero et al. (2019), exploiting administrative data from Italy, find that negative rates have expansionary effects on credit supply (and the real economy) through a portfolio rebalancing channel, rather than a deposit channel.

Few papers have analyzed risk-taking in response to negative rates for the overall investment portfolio of banks, analyzing risks stemming from securities, loans and all other assets on banks' balance sheets. These papers use the risk weighted asset (RWA) measures that are calculated by banks in order to determine capital requirements. Evidence is not unequivocal. Looking at these less granular measures that extend beyond the securities portfolio Arce et al. (2018) as well as Boungou (2020) and Reghezza et al. (2019) find a decrease in overall risk (measured as RWA or the $z$ score) after the introduction of negative rates. Basten and Mariathasan (2018) find an increase in RWA for the Swiss banks most affected by the negative interest rates policy. Using a risk measure derived from banks' equity valuations, Nucera et al. (2017) find that the risk impact of negative rates depends on banks' business models: large and more diversified banks are perceived as less risky, while smaller and more traditional banks are perceived as more risky.

Differently from all the papers mentioned above, we analyze the securities portfolios of the largest (more systemic) euro area banks and assess the impact of the introduction of negative policy rates. Focusing on the securities portfolios of German banks, Abbassi et al. (2016) find evidence of reach-for-yield behavior in response to the global financial shock associated to the bankruptcy of Lehman Brothers. Banks with higher trading expertise increased their investments in securities with higher fire sales, especially in low-rated and long-term securities. At the same time, these banks reduced their credit supply, suggesting a substitution from loans to securities yielding higher returns. Our results complement these findings, since we find evidence of changes in euro area banks' securities holdings due to changes in monetary policy, as opposed to the financial crisis. Our work is close in spirit also to the analysis of Koijen et al. (2018) which use a security-level data set on holdings for euro area sectors (e.g., the holdings at the banking sector level as well as other financial sectors). We use the holdings of a limited sample of euro area banks (albeit covering a large majority of the assets of the euro area banking sector), but we can disentangle the holdings at the level of a single banking group.

There is also evidence on how low levels of interest rates affect investment of nonbank financial intermediaries. Di Maggio and Kacperczyk (2017) find that in response to policies that maintain low interest rates, money market funds change their product offerings by investing in riskier asset classes. Choi and Kronlund (2017) analyze the investment behavior of corporate bond mutual funds. They argue that incentives for reaching-for-yield strengthen when interest rates are low. Their study shows that funds generate higher returns when they reach-for-yield, in particular in periods of low interest rates. More recently, Ozdagli and Wang (2019) show that life insurance companies, the largest institutional holders of corporate bonds, tilt their portfolios toward higher-yield bonds when interest rates decline. They argue, however, that this is mainly due to active duration adjustment of their 
portfolios in response to lower policy surrenders and lapses when interest rates decline.

\section{THE IMPACT OF NEGATIVE POLICY RATES: HYPOTHESES, IDENTIFI- CATION, AND DATA}

There is a large literature addressing the impact of monetary policy rates on banks' balance sheets. Lower policy rates decrease the cost of funding for the banks and this generally translates in higher bank net worth, because of the maturity transformation operated by banks (see, e.g., Freixas and Rochet 2008, Dell'Ariccia, Laeven, and Marquez 2014). However, negative policy rates add an additional dimension to the monetary analysis as their transmission through the banking sector is different. We analyze these issues in detail in the next section.

\subsection{The Transmission of Low (Negative) Policy Rates}

A reduction in policy rates is immediately transmitted to the general level of shortterm interest rates. Since the balance sheet of banks usually is composed by longerterm assets and shorter-term liabilities, a rate cut would generally result in increased bank net worth. This is based on the assumption that banks can immediately passthrough the rate cut to their liabilities. Therefore, banks can fund themselves at lower rates while the asset side remains largely unaffected, leading to an increase in the value difference between assets and liabilities, and hence in the net worth of banks. This in turn would relax financial constraints and increase banks' capacity to lend and invest in securities.

With positive rates, the effect of a rate cut on bank risk-taking is theoretically ambiguous (see Dell'Ariccia, Laeven, and Marquez 2014, Dell'Ariccia, Laeven, and Suarez 2017). ${ }^{9}$ On the one hand, banks' risk-taking will depend on portfolio reallocation effects. A decrease in the yield of safe assets will make them less attractive and generally increase banks' demand for risky assets. On the other hand, lower shortterm rates increase the franchise value of banks, reducing the incentives to take more risk-risk-shifting effects.

The overall effect of these countervailing factors will depend on the ability to passthrough lower rates to customers (e.g., retail customer versus wholesale funding) and the ability to change the capital structure (e.g., some banks have business models with higher retail funding, which tend to be persistent over time). Overall, negative rates induce a differential shock between high- and low-(retail) deposit banks (see also Brunnermeier and Koby 2018, Eggertsson et al. 2019). While the effects of portfolio reallocation are similar (safe assets generally become less attractive), negative rates are a financial burden for high-deposit banks, as they reduce their franchise value, thereby inducing more risk-taking.

9. We thank Skander van den Heuvel for suggesting these arguments. 


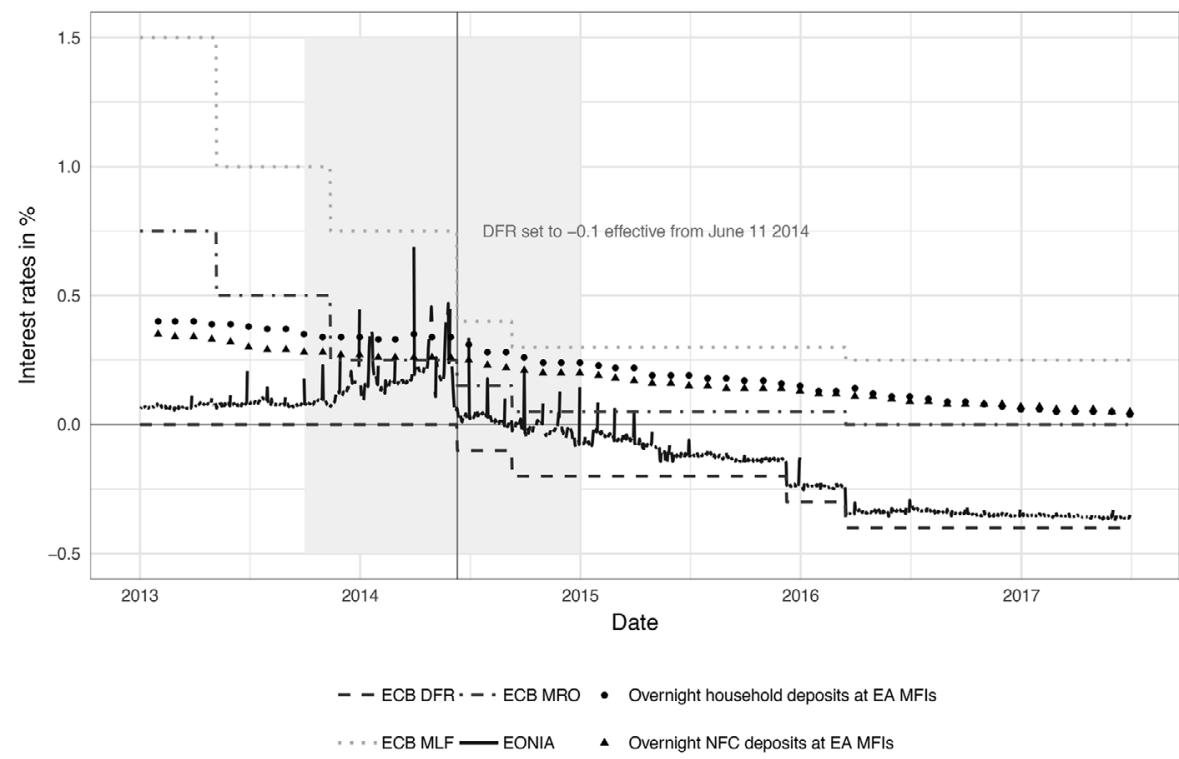

FIG 1. Policy Rates and Market Interest Rates in the Euro Area.

Notes: This figure shows a daily time series of the policy rates of the ECB and other important bank interest rates in the euro area between January 2013 and June 2017. The dashed line is the deposit facility rate (ECB DFR), the dashdotted line is the rate on main refinancing operations (ECB MRO) the dotted line is the marginal lending facility (ECB MLF) obtained from ECB SDW. The blue line is a daily series of the EONIA interbank interest rate (Euro OverNight Index Average) obtained from ECB SDW. The dots and triangles show a monthly time series of the rates applied to "new business" overnight household and NFC deposits from the euro area MFI Interest Rate Statistics obtained from ECB SDW.

Indeed, the pass-through of negative rates is somewhat different. Banks do not generally pass-through negative rates to their retail depositors but only to their wholesale depositors (see Figure 1). High-deposit banks have less wholesale deposits than low-deposit banks, ${ }^{10}$ and, as it can be inferred also from Figure 2, these funding structures are quite persistent. Banks that fund more through the wholesale market pass on negative rates to their depositors. For example, the average overnight interbank market rate in the euro area (EONIA) became negative already in the second half of 2014, shortly after the introduction of negative policy rates. Banks with more retail deposits have less wholesale funding, which implies that they are overall less able to pass the negative rates to their liabilities.

Banks may be reluctant to charge negative rates to retail depositors for several reasons, at least over short time horizons. They may not want to jeopardize longterm customer relationships, and depositors could just decide to hold currency and/or move deposits to another bank that does not charge negative rates. This may apply

10. In our sample, we found a negative correlation between deposit ratios and wholesale deposits (regression coefficient of -0.07 , $p$-value: 0.01 ), see also Figure A5. 


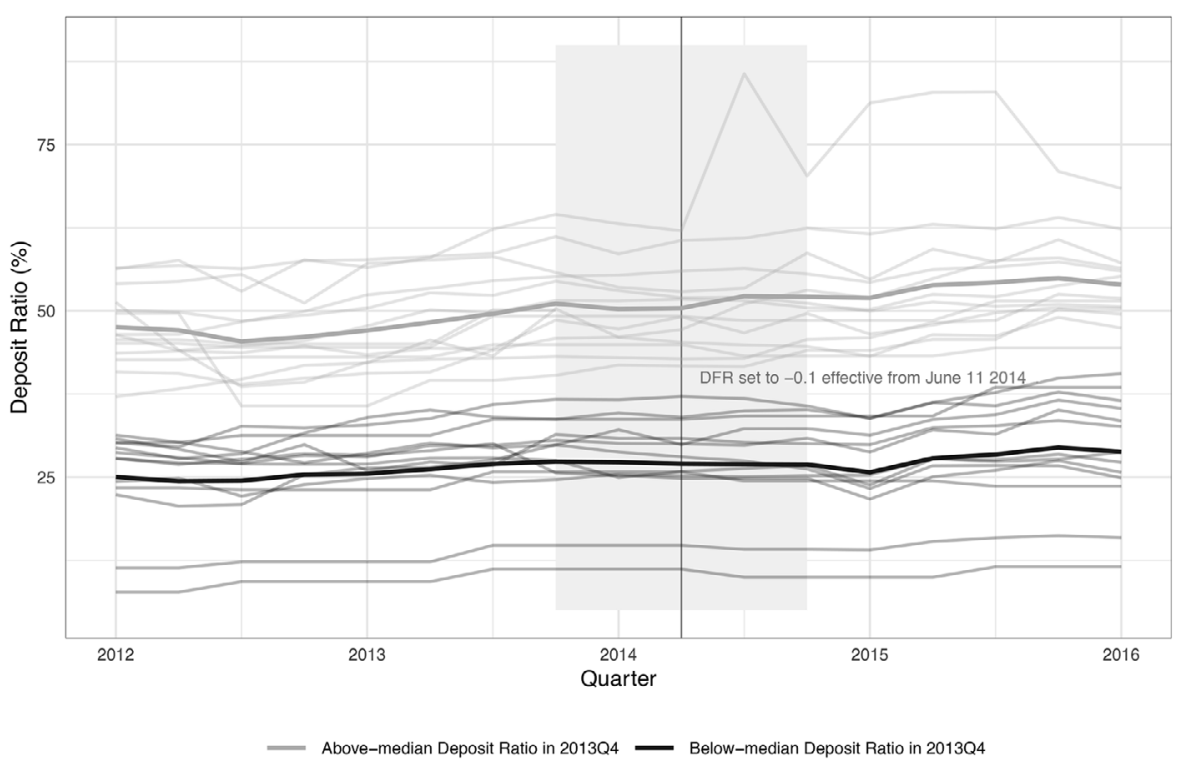

FIG 2. The Evolution of the Deposit Ratio over Time.

Notes: This figure shows a quarterly time series of the Deposit Ratio (in \%) between Q1 2012 and Q1 2016 obtained via SNL Financials for each bank in our sample. We compute the Deposit Ratio by dividing Customer Deposits in Euro by Total Assets in Euro. Banks are also classified into above-median Deposit Ratio banks and below-median Deposit Ratio banks according to their Deposit Ratio in Q4 2013. The yellow thick line shows a quarterly average for above-median Deposit Ratio banks, and the light yellow lines show the deposit ratio for each of these banks. The blue thick line shows a quarterly average for below-median Deposit Ratio banks, and the light blue lines show the deposit ratio for each of these banks.

especially to customer deposits that are typically smaller in size. There may also be legal constraints in charging negative deposit rates, due to the institutional setting of some deposit-taking corporations (like cooperative banks for example). ${ }^{11}$

Banks may compensate for the effects of negative rates by increasing customer fees for their services. Reliable data on fees are hard to obtain and we do not have it for our sample of banks during the time period that we are considering. As a proxy, we have looked at the values of noninterest income. As shown in the last column of Table A3, noninterest income does not change significantly more for high-deposit banks compared to low-deposit banks after the introduction of negative interest rates. This is consistent with evidence shown in Altavilla et al. (2019), where they find no

11. Altavilla et al. (2019) provide some recent evidence based on euro area banks. They show that as of end-2018 negative interest rates applied only to around 5\% of total euro area deposits. However, there is considerable heterogeneity across countries and sectors: about $50 \%$ of German corporate deposits are placed with banks that report average deposit rates at levels below zero. At the same time, the average interest rate applied to this type of deposits across the whole German banking sector has never fallen below $-0.03 \%$. We refer to the series "Overnight deposits, Total original maturity, New business coverage, NonFinancial corporations (S.11) sector, denominated in Euro" in the publicly available MFI Interest Rate Statistics. See also Figure 1 for a time series of the euro area aggregate. 
evidence of a substitution of rates by fees within a sample of more than 200 large euro area banks. They show that "banks with a large proportion of deposits always charge lower fees and do not change their behavior after the implementation of the NIRP." 12

All in all, based on the theoretical literature and on institutional practices in the banking sector, the testable predictions (hypotheses) from the introduction of negative rates imply that more affected banks are the ones with higher ex ante retail deposits, and these banks will respond to NPR by taking more risk. The intensity of the treatment induced by the introduction of NPRs therefore varies across banks with the degree to which they are funded by customer deposits. This enables us to identify the effect of negative interest rates on the securities holdings of banks.

\subsection{Identification Approach}

Policy rates in the euro area moved into negative territory in June 2014, when the ECB lowered the deposit facility rate (DFR) to $-0.10 \%$. Three further reductions in the policy rate brought the rate on the deposit facility to $-0.40 \%$ by March 2016 (see Figure 1 for the evolution of the policy rates in the euro area).

In the current economic and institutional environment, central bank liquidity is allocated on a full allotment basis and a series of nonstandard monetary policy measures are in place. In aggregate, euro area commercial banks hold a substantial amount of excess liquidity at the central bank, that is, more liquidity than they need to fulfil reserve requirements. While required reserves are remunerated at an interest rate equal to the main refinancing operations (MRO) rate, ${ }^{13}$ excess reserves held by euro area banks are charged a negative deposit facility rate since June $2014 .{ }^{14}$

Our main identification argument is based on the limited pass-through of NPRs to the rates paid on retail deposits. Eisenschmidt and Smets (2018) show that by the end of 2016, in some core European countries, banks started to charge negative deposit rates but only to corporations (e.g., $-0.03 \%$ on average in Germany as of April 2019), while rates for households deposits remained positive. This suggests that eventually the pass-through of negative rates may take place, but it is more sluggish than with positive rates and it may affect only certain types of customers (see also Eggertsson et al. 2019, Heider, Saidi, and Schepens 2019).

There is ample cross-sectional variation in terms of retail deposit ratios across our sample. Figure 2 shows that the large euro area banks in our sample fund between $20 \%$ and $60 \%$ of their balance sheet via customer deposits. Over time, deposit ratios are rather sticky, as it is shown in Figure 2. In terms of volume, we note that after

12. They show that the deposit ratio has a negative correlation with the dependent variable Fees and commissions and that the coefficient of the interaction Deposit Ratio*Post is not statistically significant.

13. See also Article 8 of Regulation (EC) No 1745/2003 of the ECB of September 12, 2003 on the application of minimum reserves (ECB/2003/9).

14. Only in October 2019 a two-tier system for remunerating excess reserve holdings was introduced by the ECB. 
the introduction of negative rates there was an increase in deposits for high-deposit banks compared to low-deposit banks. ${ }^{15}$

We use a difference-in-differences specification to analyze how the holdings of a particular security change in response to the introduction of NPRs, differentiating between high-(retail) deposit ratio banks and low-deposit ratio banks. As argued above, banks with different deposit ratios are affected differentially when policy rates reach negative territory and this provides a way to identify the effects of NPRs on bank risk-taking in securities (i.e., reach-for-yield) and isolate them from other forces that shape both monetary policy and the investment behavior of large euro area banks.

We investigate if banks with a larger retail depositor base invest in higher-yielding securities after NPR. We analyze the data at the security-bank-quarter level. This allows us to test whether the reaction to the introduction of NPR differs with certain (observed) bank characteristics (deposit ratio) for high versus low yielding securities (reach-for-yield), controlling for unobserved bank and security heterogeneity (e.g., bank risk and issuance of some securities).

The analysis is based on a difference-in-differences estimation where we capture the effect of monetary policy through a dummy variable that equals 1 when policy rates are below zero. The ECB deposit facility rate was set to $-0.10 \%$ effective from June 11, 2014. We classify the period Q4 2013-Q1 2014 as the pre-NPR period and Q2 2014-Q4 2014 as the post-NPR period. We stop our analysis at the end of 2014 so that we can interpret our findings as resulting from the introduction of NPRs, excluding the following period when the ECB announced and then implemented the expanded APP, that is, the euro area QE. ${ }^{16}$ We choose to stop our analysis at the end of 2014 because extending the time period further would overlap with the period in which central bank asset purchases were carried out. Obviously, this policy action has a direct impact on the securities holdings of banks and may have affected banks differently, depending on their ex ante securities allocation, possibly confounding our results.

Our dependent variable is the holdings of the security by a certain banking group in a certain quarter. The main coefficient of interest is the interaction term Deposit Ratio*Post*Yield. Identification relies on the Deposit Ratio, the ratio of customer deposits over total assets. Post is a dummy variable equal to one for the period June 2014 onward. The variable Yield is a risk measure based on the ACY of a security (please refer to Section 1.3 for details on how we compute Yield). We include the total assets and the ratio of equity over total assets (i.e., the equity ratio of the bank) as controls. We also include fixed effects, for example, bank or security fixed effects.

15. See Figure A3.

16. During the period that we consider there were other measures of nonconventional monetary policy that were undertaken. In June 2014, the ECB announced the two TLTROs with allotments taking place in September 2014 and December 2014. It is not clear ex ante, why the TLTRO take-up would differ across large banks with different deposit ratios and therefore affect the results of our analysis. Bottero et al. (2019) construct a bank-level measure of borrowing capacity and show that it does not affect changes in loan supply immediately after the introduction of negative rates. Heider, Saidi, and Schepens (2019) perform their analysis until the end of 2015 and run robustness checks for the subperiod of 2014. Moreover, our results are significant even before the TLTRO implementation (see Figure 3). 
In all our specifications, we double cluster standard errors at the security and banktime level.

We employ fixed effects to control for the factors that can explain banks' investment in certain securities, such as regulatory pressures, or issuance of particular securities (the supply of securities), for example, the need to raise funding. A major development in the regulatory landscape during the period that we analyze was the implementation of the Single Supervisory Mechanism (SSM) in the euro area and the transfer of the direct supervision of large euro area banks from the national supervisory authorities to the ECB. All the banks in our sample were affected by this change and their direct supervision was transferred from the national competent (supervisory) authorities to the SSM. The SSM became operational in November 2014, and Figure 3 shows that our results are significant before November 2014, though preparatory work was undergoing during the period that we analyze. Similarly, other regulatory measures were being implemented, in particular the Liquidity Coverage Ratio (LCR), which came into effect in October 2015. Our results would be affected by these developments if changes in regulation would have a differential impact across banks with low and high deposit ratios during our estimation window in the years 2013-14. Related to the implementation of the LCR, it can be argued that the LCR is likely to have created incentives to invest in liquid assets, yielding lower returns, as opposed to riskier and higher-yielding securities (see also the related discussion in Heider, Saidi, and Schepens 2019).

\subsection{Data}

Securities holdings are an important fraction of bank balance sheets. On average, they account for around $20 \%$ of total banking assets in the euro area. The main database used in the analysis is the new Securities Holdings Statistics by Group (SHSG) database of the Eurosystem. The database contains at the level of each banking group security-level information on the securities holdings for 26 reporting banking groups legally incorporated in the euro area (see Table A1). It covers the large majority of the euro area banking sector in terms of financial assets. Data are collected on a quarterly basis since Q4 2013. The SHSG database provides information on holdings at the security level as identified by ISIN. For the purpose of the analysis in this paper, we focus on the holdings of debt securities (both short term and long term) and enrich the database with security level information-like rating, coupon rates, prices, and maturity - from the Eurosystem Centralised Securities Database (CSDB). ${ }^{17}$ Data on banks' balance sheets are from SNL Financials.

Using information on the issuer of the debt securities, we classify the assets in four broad categories. Securities are classified as Public Debt if they are issued by the sectors "General Government" "Central Bank" as well as by certain supranational institutions such as the European Investment Bank (EIB) or the European Stability

17. On average, the percentage of the securities portfolio invested in equities is below $5 \%$ for the banking groups in our sample. 
TABLE 1

Average Total Nominal Holdings by Asset Class and Region

\begin{tabular}{|c|c|c|c|c|}
\hline & \multicolumn{2}{|c|}{ Q4 2013-Q1 2014} & \multicolumn{2}{|c|}{ Q2 2014-Q4 2014} \\
\hline & Euro billion & $\%$ & Euro billion & $\%$ \\
\hline \multicolumn{5}{|l|}{ Asset class } \\
\hline $\begin{array}{l}\text { ABS } \\
\text { Private debt (other) } \\
\text { Private debt issued by banks } \\
\text { Public debt }\end{array}$ & $\begin{array}{c}524.8 \\
485.5 \\
830.8 \\
1,100.7\end{array}$ & $\begin{array}{l}17.8 \% \\
16.5 \% \\
28.2 \% \\
37.4 \%\end{array}$ & $\begin{array}{l}521.4 \\
403.0 \\
754.7 \\
1,141.9\end{array}$ & $\begin{array}{l}18.5 \% \\
14.3 \% \\
26.8 \% \\
40.5 \%\end{array}$ \\
\hline \multicolumn{5}{|l|}{ Currency } \\
\hline $\begin{array}{l}\text { CHF \& GBP } \\
\text { EUR } \\
\text { Other } \\
\text { USD }\end{array}$ & $\begin{array}{c}46.5 \\
2,390.7 \\
283.1 \\
221.4\end{array}$ & $\begin{array}{l}1.6 \% \\
81.3 \% \\
9.6 \% \\
7.5 \%\end{array}$ & $\begin{array}{c}42.9 \\
2,275.1 \\
283.0 \\
219.9\end{array}$ & $\begin{array}{l}1.5 \% \\
80.7 \% \\
10.0 \% \\
7.8 \%\end{array}$ \\
\hline Total & $2,941.7$ & & $2,821.0$ & \\
\hline
\end{tabular}

NoTES: This table displays the average total nominal holdings of securities by all 26 banks in the SHSG database both in period before the introduction of negative policy rates (Q4 2013-Q1 2014) and after the introduction of negative policy rates (Q2 2014-Q4 2014). The top panel splits all holdings by asset class (issuer and debt type). The lower panel splits securities by the currency of issuance.

Mechanism (ESM). Securities from private issuers are grouped into three distinct categories. Securities issued by "Deposit-taking corporations except the central bank" are classified as "Private debt issued by banks." "Asset-backed securities" includes different types of securitized debt: covered bonds, mortgage backed securities (MBS), Pfandbrief, collateralized debt obligations (CDOs), and other ABS. The asset class "Private debt (other)" is a residual category and includes debt issued by financial corporations other than banks and by the nonfinancial corporate sector.

Table 1 shows the average total nominal holdings (and the holdings share) for the four asset classes considered, both before and after the introduction of NPRs. Overall, there was a broad disinvestment from debt securities issued by euro area banks and other private issuers, while there was some increase in the percentage of the portfolio invested in public debt and in ABS securities.

To compare investment in financial assets with different yield patterns (reach-foryield), we use the ACY measure as in Abbassi et al. (2016). Differences in risk can explain differences in the yield of otherwise similar securities. In the SHSG database, the banking groups report the value of their holdings both in nominal terms and valued at market prices along with the number of securities held at the end of the quarter. To obtain prices for all securities in our database, we rely on this information as opposed to using external sources. We compute the prices by dividing the reported market value of the holdings of a certain ISIN by the number of securities that the bank holds. We obtain the information on coupon rates and residual maturities from the CSDB of the Eurosystem. ${ }^{18}$

18. See also Table 2 in "Who holds what - new information on securities holdings" (ECB Economic Bulletin, Issue $2 / 2015$, p. 75). 
TABLE 2

SumMary Statistics

\begin{tabular}{lccccc}
\hline \hline Security-level variables & $N$ & mean & sd & min & $\max$ \\
\hline Yield (ACY) & 404,039 & 0.884 & 4.104 & $*$ & $*$ \\
Rating & 280,087 & 6.024 & 4.263 & 1 & 18 \\
Ln(Holdings) & 404,039 & 14.22 & 3.619 & $*$ & $*$ \\
Holdings (Euro billion) & 404,039 & 0.03 & 0.27 & $*$ & $*$ \\
Post & 404,039 & 0.617 & 0.486 & 0 & 1 \\
Maturity (Years) & 404,039 & 7.353 & 11.09 & $*$ & $*$ \\
\hline Bank-level variables & $N$ & mean & sd & min & $\max$ \\
\hline Total assets in Euro 100 billion (from SNL) & 131 & 6.27 & 5.06 & 0.74 & 20.78 \\
Log(Total Assets) (from SNL) & 131 & 26.84 & 0.825 & 25.02 & 28.36 \\
Equity/Total Assets in \% (from SNL) & 131 & 5.098 & 1.321 & 3.109 & 8.167 \\
Customer deposits/Total Assets in \% (from SNL) & 131 & 39.26 & 14.25 & 9.943 & 85.68 \\
Customer deposits in Euro billion (from SNL) & 131 & 237.6 & 184 & 10.59 & 713.2 \\
Noninterest income in Euro billion (from SNL) & 75 & 1.029 & 1.252 & -0.338 & 4.965 \\
Total net loans in Euro 100 billion (from SNL) & 100 & 2.881 & 1.959 & 0.9082 & 7.571 \\
\hline Loan-level variables & $N$ & mean & sd & min & $\max$ \\
\hline Loan amount in Euro million (Dealogic) & 564 & 51.21 & 50.13 & 0 & 266.7 \\
Rating (Dealogic) & 128 & 9.398 & 2.131 & 5 & 15 \\
\hline
\end{tabular}

Notes: This table shows summary statistics of the variables included in our regressions (Q4 2013-Q4 2014). All security-level variables are obtained from SHSG: The Yield (ACY) is the adjusted current yield computed with price information from the Centralized Securitie Database (CSDB) of the Eurosystem, Rating is a numerical variable based on the most frequent rating of a security in the CSDB (AAA corresponds to 1), Maturity is top-coded at 100 years. All bank-level variables are obtained on the banking group level via SNL Financials. Loan-level variables are from Dealogic. Confidential data points from the securites register (SHSG data) were omitted.

We compute the ACY of a security as:

$$
\text { Yield }=100 \cdot \frac{\text { Coupon }[\% \text { ann. }]}{\text { Price }}+\frac{100-\text { Price }}{\text { Residual Maturity } / 365}
$$

We include in the sample all securities with a nominal holding amount that at some point exceeded 0.5 million euro, summing up the holdings of the 26 reporting banking groups. Furthermore, we trim our data according to the variable ACY and include all securities with an adjusted current yield between the 5th and the 95th percentile of the overall distribution. ${ }^{19}$ Table 2 shows summary statistics of our sample, in particular a large variation across securities yields, as well as bank retail deposit ratios.

19. Over the time frame considered in our analysis, the cross-sectional distribution of the ACY shifts to the left, partly as a result of lower policy rates. Therefore, at the end of 2014 a large fraction of the securities portfolio of the largest euro area banks was yielding a negative return. Figure A1 shows how the overall distribution of the ACY (weighted by the nominal holding amount) for the securities holdings in our sample changed between Q4 2013 (the beginning of our sample) and Q4 2014 (the end of our sample period). Note that the ACY values securities at current market prices. Banks do not necessarily incur losses on their holdings at negative values of the ACY, for example, since securities may have been bought earlier at different prices. 


\section{RESULTS}

In this section we show our main results, in particular the reach-for-yield associated to the introduction of NPRs. Moreover, we analyze how the effects of negative interest rates evolve over time and test the parallel-trends assumption. In addition, we look at the heterogeneity of effects across distinct asset classes and currencies, and how these effects vary with the maturity of securities, as well as with banks' equity ratios. Finally, we analyze lending.

\subsection{Negative Monetary Policy Rates and Reach-for-Yield}

The dependent variable is the (log-transformed) holdings of a security by each bank in a certain quarter. Before our benchmark results in Table 4, the results in Table 3 show that, overall, securities holdings decreased during the implementation of NPRs (see negative coefficient of Post) in columns (1)-(3). The fourth column additionally controls for the risk of a security via the ACY. Not surprisingly, given the reduction in policy rates, deleveraging was stronger for riskier securities with a higher yield, see the negative coefficient of Post*Yield. This holds across different specifications with bank and security fixed effects (columns (4)-(9) in Table 3).

To identify the link between NPRs and reach-for-yield behavior, we estimate a difference-in-differences specification where identification is provided by banks' reliance on customer deposits. We compare banks that were more affected by the introduction of negative interest rates to a control group that was less affected. Thereby, we can disentangle the effects that are due to changes in the supply of securities, or driven by other economic developments, from those effects that we can attribute to the introduction of negative interest rates by the ECB.

Results are reported in Table 4 with different sets of fixed effects on the bank- and security level. Our dependent variable is the (log-transformed) holdings of a security by each bank in a certain quarter. First, we find that the coefficient of Deposit Ratio*Post is positive, thereby implying higher security holdings for banks with higher retail deposits after the introduction of NPR. Second, the estimated coefficient of the interaction Deposit Ratio*Post*Yield shows that the impact of an increase in the ACY in the post-NPR period was significantly different for banks with a higher retail deposit ratio. This can be interpreted as evidence of (relative) reach-for-yield behavior induced by the introduction of NPRs. Based on the coefficient of Deposit Ratio*Post*Yield in the third column of Table 4, we find that after the introduction of NPRs, a difference in the deposit ratio of 10 percentage points (approximately one standard deviation) would imply an around 2 percentage points increase in the sensitivity of the holdings of a particular security in response to a change in the ACY by 1 percentage point. ${ }^{20}$ The coefficient of the triple interaction Deposit Ratio*Post*Yield

20. Both the ACY (cf. Figure A1) and the deposit ratio (cf. Figure 2) are measured in percentage points, while the dependent variable of nominal holdings has been log-transformed. 
TABLE 4

Benchmark Model (Incl. Deposit Ratio Interaction)

\begin{tabular}{lcccccc}
\hline \hline & $(1)$ & $(2)$ & $(3)$ & $(4)$ & $(5)$ & $(6)$ \\
\cline { 2 - 7 } & \multicolumn{7}{c}{ Dependent variable: Securities holdings } \\
\hline Post & $-2.140^{*}$ & $-2.245^{*}$ & $-1.558^{* *}$ & $-1.704^{* *}$ & $-1.204^{* *}$ & $-0.655^{* *}$ \\
& $(1.192)$ & $(1.138)$ & $(0.648)$ & $(0.738)$ & $(0.494)$ & $(0.307)$ \\
Deposit Ratio (DR) & 0.00911 & -0.0149 & $-0.0403^{*}$ & -0.00588 & $-0.0308^{* *}$ & $-0.0181^{*}$ \\
& $(0.00712)$ & $(0.0115)$ & $(0.0204)$ & $(0.00704)$ & $(0.0155)$ & $(0.00941)$ \\
Yield & -0.0255 & -0.0164 & 0.0188 & -0.0142 & 0.00133 & 0.0103 \\
& $(0.0158)$ & $(0.0167)$ & $(0.0203)$ & $(0.0167)$ & $(0.0133)$ & $(0.0111)$ \\
Post* Yield & $-0.164^{* *}$ & $-0.155^{* *}$ & $-0.116^{* * *}$ & $-0.0914^{* * *}$ & $-0.0655^{* * *}$ & $-0.0377^{* *}$ \\
& $(0.0755)$ & $(0.0698)$ & $(0.0439)$ & $(0.0334)$ & $(0.0206)$ & $(0.0187)$ \\
DR*Post & 0.0388 & $0.0426^{*}$ & $0.0323^{* *}$ & $0.0322^{* *}$ & $0.0251^{* * *}$ & $0.0132^{* *}$ \\
& $(0.0240)$ & $(0.0234)$ & $(0.0136)$ & $(0.0150)$ & $(0.0104)$ & $(0.00639)$ \\
DR*Yield & 0.000246 & $3.80 \mathrm{e}-05$ & $-0.000795^{*}$ & 0.000756 & $-4.75 \mathrm{e}-05$ & -0.000364 \\
& $(0.000400)$ & $(0.000404)$ & $(0.000426)$ & $(0.000526)$ & $(0.000335)$ & $(0.000306)$ \\
DR*Post* Yield & $0.00294^{*}$ & $0.00282^{*}$ & $0.00224^{* *}$ & $0.00163^{* *}$ & $0.00136^{* *}$ & $0.000835^{*}$ \\
& $(0.00165)$ & $(0.00154)$ & $(0.00100)$ & $(0.000760)$ & $(0.000533)$ & $(0.000442)$ \\
Observations & 402,649 & 402,649 & 402,649 & 386,551 & 386,551 & 353,771 \\
$R^{2}$ & 0.042 & 0.062 & 0.223 & 0.473 & 0.582 & 0.862 \\
Bank Controls & No & Yes & Yes & Yes & Yes & Yes \\
Bank FE & No & No & Yes & No & Yes & - \\
Security FE & No & No & No & Yes & Yes & - \\
Security*Bank FE & No & No & No & No & No & Yes \\
\hline
\end{tabular}

NoTES: This table shows regressions on the security-level (ISIN) for quarterly observations between Q4 2013 and Q4 2014. The dependent variable Ln(Holdings) is calculated on nominal amounts and is determined by the holdings of security $i$ by bank $j$ at the end of quarter $t$. Post is the coefficient of a dummy variable that equals 1 from Q2 2014 onward (negative policy rates were announced in June 2014). Deposit Ratio is calculated as Customer Deposits over Total Assets (in \%). The Yield is the adjusted current yield (in \%) of a security. Standard errors are double clustered on the security and bank-time level. Bank controls include the Equity Ratio (computed as Equity/Total Assets) and log(Total Assets). The different sets of fixed effects are marked with "Yes" if they are included in the regressions and "No" otherwise, additionally absorbed fixed effects are marked with "-". *** $p<0.01, * * p<0.05, * p<0.1$.

is positive and significant both between banks (or securities) and within, exploiting within-security variation and within-bank variation. ${ }^{21}$

Overall, the post-NPR portfolio of high-deposit ratio banks becomes riskier compared to low-deposit ratio banks, suggesting reach-for-yield in securities holdings caused by the introduction of negative interest rates. This (ex post) result is consistent with our (ex ante) hypothesis. Banks that are more reliant on customer deposits are more affected by negative rates and increase risk-taking by reaching for higher yields (cf. Section 1.1).

We now explore the potential drivers of higher securities holdings for high-deposit banks after NPR. Figure 2 shows the evolution of the deposit ratio across the banks

21. The sign of the triple interaction is also robust across subsamples restricted to the bottom quartile, the two midquartiles and top quartile of the ACY. Very small holdings (below 0.5 million on aggregate) are typically just held by a single bank and therefore excluded in our baseline estimations. However, our results are robust to including all reported securities holdings including reported zero holdings as well as to a weighted estimation of our benchmark regression, with weights based on the overall holdings of each security (see first four columns of Table A2). Moreover, if we control for the correlations between a security and the portfolio of securities by a bank (e.g., different shares in sovereign debt, private securities, and foreign securities), results are virtually the same (see the last two columns of Table A2). 
in our sample. We have split the sample in two groups of banks, below and above the median for the deposit ratio. There were limited changes in the deposit ratios of the two groups of banks after the introduction of negative policy rates. Consistently, the overall amount of customer deposits of high-deposit banks indeed increased somewhat after the introduction of negative policy rates (see Figure A3). This suggests that there were indeed more deposit inflows toward high-deposit banks compared to low-deposit banks. ${ }^{22}$

Table A3 shows the results of bank level panel regressions, controlling for unobserved bank heterogeneity via bank fixed effects, which provide further evidence based on the banks in our sample. The first column shows indeed that deposits were flowing relatively more to high-deposit banks after the introduction of negative rates. At the same time, the second column shows that the volume of loans did not change similarly and that high-deposit banks did not increase loans relative to low deposit ratio banks. We can infer from this evidence that high-deposit banks preferred to invest the additional deposit inflows in (liquid) securities holdings that are easier to readjust than (illiquid) loans (as these new deposits could unexpectedly reverse themselves).

\subsection{The Parallel-Trends Assumption}

Our identification strategy relies on the assumption that, in the period before the introduction of negative policy rates, risk-taking behavior did not differ systematically across banks with low and high deposit ratios (parallel-trends assumption). To investigate further on this, we estimate a specification that includes dummies for the lags and leads of the policy change, as in Autor (2003). Instead of the interaction with Post, we include interactions with a dummy variable for each quarter. These dummy variables take a value of 1 in the respective quarter and a value of 0 for all other quarters. Figure 3 shows all estimated coefficients of the interactions of deposit ratio, ACY and dummy variables for each quarter with $90 \%$ confidence bands. Without a systematic difference before and after the policy change, we would expect the pretreatment interaction of a quarter dummy with the deposit ratio and the yield to be close to zero (not statistically significant). Our data are available from the fourth quarter of 2013 onward and we use the quarter before the introduction of NPRs (Q1 2014) as our reference period. Before the policy change, the estimated coefficient of the triple interaction of Deposit Ratio, Yield and the dummy variable for Q4 2013 is not statistically (and economically) significant. Based on this evidence, we do not reject the parallel trend assumption during the pre-NPR period.

Figure 3 also illustrates the effects of negative interest rates over time: the strongest effect is already visible at the end of the second quarter (negative policy rates were first implemented on June 11, 2014), while the subsequent reduction in remuneration

22. High deposit banks have a business model that is catered more to retail customers. They may offer better deposit rates, but also better services, more branches, etc. Also, for the banks in our sample, we can show that high-deposit banks tend to have higher levels of equity and less wholesale funding, hence they are probably perceived to be safer banks, and hence preferred by depositors (see Figure A4). 


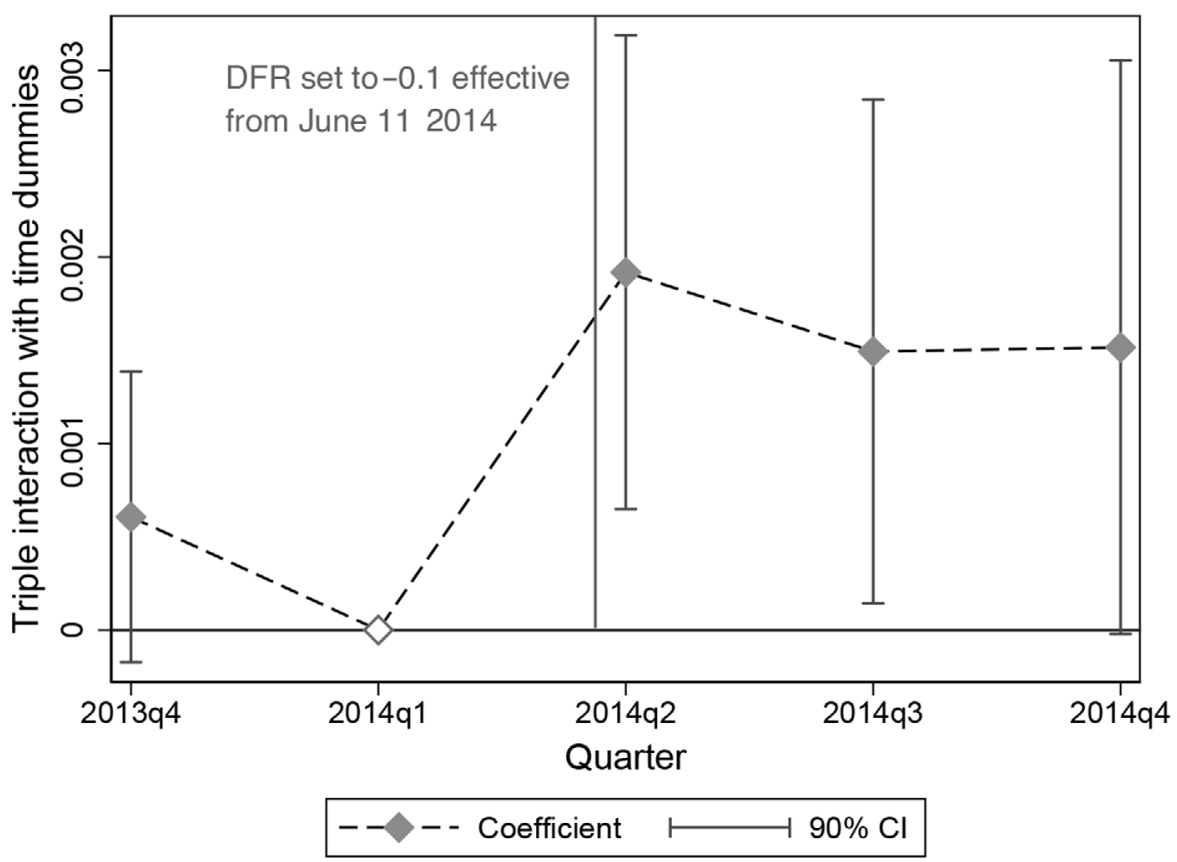

FIG 3. Evidence on the Parallel Trends Assumption.

Notes: This figure shows the triple interaction coefficient Deposit Ratio*(Pre/Post) Quarter*Yield in a regression with dummies for each quarter instead of the dummy variable and bank and security fixed effects. We plot each coefficient with a $90 \%$ confidence interval at the respective value of the variable quarter on the $x$-axis. Please note that the coefficient for Q1 2014 is 0 by construction (reference period, omitted from the regressions).

of the ECB's deposit facility on 10 September to $-0.2 \%$ had a more limited impact. The results of this test also provide a rationale to define the time frame of our analysis and to pin down the effects of the policy change in the second quarter of 2014. Indeed, if we included this quarter in our pre-NPR period, we would violate the parallel trends assumption, which would prevent us from identifying a causal effect. On the other hand, as we end our sample before the announcement of the ECB asset purchases in January 2015, the time window of our analysis includes the two quarters before and the three quarters after the introduction of negative policy rates. For robustness, we have carried out a similar analysis in a specification with just two periods. ${ }^{23}$ We can also extend the post-NPR period by up to three quarters in 2015 and our findings still hold. We cannot run a similar exercise for the pre-NPR period, because the SHSG database starts in Q4 2013.

23. We find similar results if we summarize the holdings Q4 2013-Q1 2014 and Q2 2014-Q4 2014 and estimate a simple two-period specification. 


\subsection{Asset Class and Currency Denomination}

We have shown a reach-for-yield channel after the introduction of negative policy rates. Using the granular database at our disposal, we now explore in which types of securities banks increase and decrease holdings in the process of facilitating this reach-for-yield channel. We answer the following question: is the evidence of reachfor-yield behavior by high deposit ratio banks prevalent for certain asset classes? We perform the same estimations as in Table 4 restricting our sample across different asset classes. In this specification, we include fixed effects for securities in the same rating category, and with similar residual maturity. The rationale for these fixed effects is to group securities that need a similar amount of regulatory capital. ${ }^{24}$

The left panel of Table 5 reports the results of each separately estimated regression. The positive relationship captured by the coefficient of Deposit Ratio*Post*Yield is confirmed for all asset classes, albeit at different levels of statistical and economic significance. Evidence for reach-for-yield behavior of high deposit ratio banks is strongest and statistically significant for private debt securities issued by financial and nonfinancial corporations. Relative differences in behavior between affected banks and less affected banks are particularly pronounced within this asset class. More affected banks direct their investment more toward riskier debt in the class of private debt securities compared to the relative shifts within other asset classes. Effects are not significant for sovereign debt, and are large but not statistically significant for ABS (the estimated coefficient is large but the standard errors are much larger than in the other columns).

The investment of banks in securities denominated in currencies other than the euro is important because it tackles the international spillovers of monetary policy. ${ }^{25}$ In particular, it represents a channel through which euro area (accommodative) monetary policy leaks to other economic areas and currencies. Therefore, we also consider portfolio shifts across different currencies. We estimate our relationship separately across different currencies in the right panel of Table 5. The differential response by high deposit ratio banks is particularly pronounced for securities denominated in USD. Sensitivities in this category are estimated to be almost twice the size of those for securities denominated in euro (see columns (5) and (6) of Table 5). Interestingly, we observe a counteracting effect for securities issued in Swiss Franc (CHF), British Pound (GBP), and other currencies. However, investment in these currencies represents a very small fraction of the total portfolios of the banks in our sample, therefore the economic significance of these effects is rather limited. Nevertheless, these findings of reach-for-yield behavior in USD are evidence of a

24. We construct these fixed effects as follows: First, we group securities by maturity. We use multiples of 100 days (i.e., the first group contains all securities maturing between 0-99 days, the second group those with 100-199 remaining days of maturity, etc.). Based on this, we compute a common fixed effect for securities within the same maturity group, holding the same rating during a certain quarter.

25. See, for example, Obstfeld (2019), Morais et al. (2019), or Rajan's (2014) complain on U.S. QE as RBI governor in an interview with Bloomberg (https://www.bloomberg.com/news/articles/2014-0131/india-vs-dot-the-u-dot-s-dot-when-central-bankers-collide). 


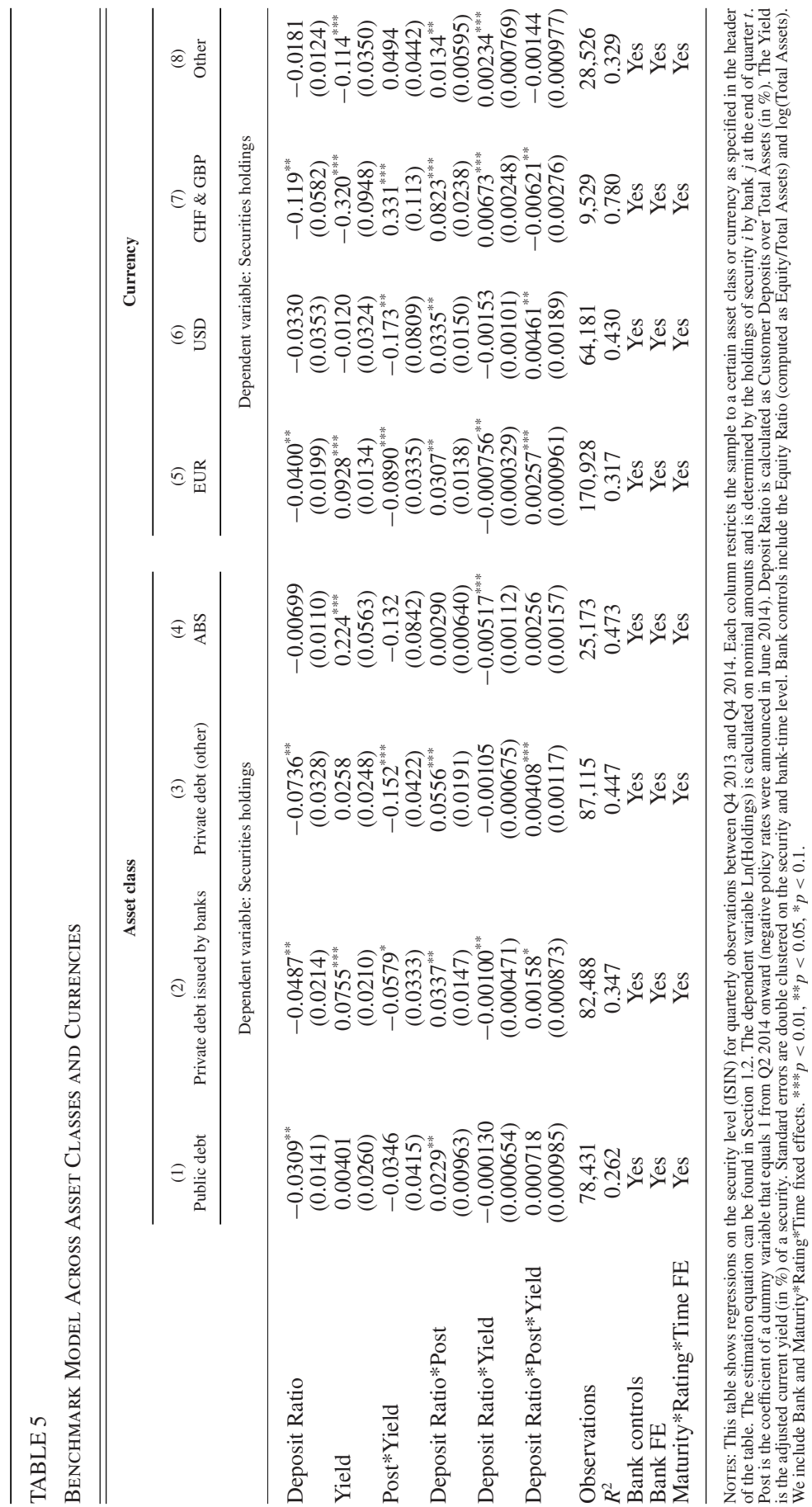


"leakage" effect of euro area monetary policy in securities markets outside the euro area.

\subsection{Bank Capital and Risk-Shifting}

Peydró, Polo, and Sette (2017) provide evidence that bank risk-taking in response to a monetary policy loosening during a crisis period can be explained by banks' riskbearing capacity (i.e., bank equity). Their analysis is based on granular data on loans and securities holdings of Italian banks. We also investigate how differences in bank equity affect securities holdings in the context of negative rates. Hence, we interact our coefficient of interest with the equity ratio (equity divided by total assets) of each bank. ${ }^{26}$ The results are displayed in Table 6.

First, we observe that the coefficient of Deposit Ratio*Post*Yield remains positive and significant for all the different specifications. To evaluate how the deposit ratio and bank capital interact, we look at the coefficient of the quadruple interaction Equity Ratio*Deposit Ratio*Post*Yield. The coefficient of the interaction is always negative and significant for some specifications. After the introduction of negative policy rates, among the most affected banks (with higher retail deposits), banks with a higher level of equity took less risk. Banks with a weaker capital position take on more risk associated to the retail deposit channel of negative rates. Therefore, our results suggest risk-shifting via the retail deposit channel as outlined in Section 1.1. At the same time, the positive coefficient of Equity Ratio*Post*Yield confirms the findings of Peydró, Polo, and Sette (2017) during the sovereign debt crisis in the euro area. ${ }^{27}$

\subsection{Duration Risk}

Duration risk is an additional dimension through which banks' securities portfolios can become riskier. We measure duration risk via maturity. ${ }^{28}$ To explore how duration risk interacts with risk-taking behavior after the introduction of negative policy rates, we estimate our benchmark specification from Section 2.1 and include maturity as an additional measure of risk (see Table 7). In particular, we are interested how maturity interacts with our main coefficient of interest Deposit Ratio*Post*Yield. We also confirm that the estimated coefficient Deposit Ratio*Post*Yield remains positive and significant, that is, robust to the addition of maturity as a control.

In addition, the positive and significant coefficient of the quadruple interaction Maturity*Deposit Ratio*Post*Yield suggests that reach-for-yield behavior is stronger for longer-term securities. This suggests that, after the introduction of negative rates,

26. In general, there is no mechanical relationship between the deposit ratio and the equity ratio since more equity funding does not necessarily decrease the ratio of deposits over total assets. Rather, we find a slightly positive relationship between the retail deposit ratio and the equity ratio for the banks in our sample (see also Figure A4).

27. This leads to a counteracting effect that quantitatively dominates the overall relationship.

28. Figure A2 shows the maturity structure of the securities holdings in our sample before and after the introduction of NPRs. There were no significant aggregate shifts in the maturity structure during our sample period. 
TABLE 6

Benchmark Model with Additional Bank Equity Ratio Interaction

\begin{tabular}{|c|c|c|c|c|c|c|}
\hline \multirow[b]{3}{*}{ Post } & (1) & (2) & (3) & (4) & (5) & (6) \\
\hline & \multicolumn{6}{|c|}{ Dependent variable: Securities holdings } \\
\hline & $\begin{array}{l}-4.954 \\
(4.038)\end{array}$ & $\begin{array}{l}-4.801 \\
(3.989)\end{array}$ & $\begin{array}{c}-5.886^{* * *} \\
(2.056)\end{array}$ & $\begin{array}{l}-3.998 \\
(2.501)\end{array}$ & $\begin{array}{c}-4.699^{* * * *} \\
(1.572)\end{array}$ & $\begin{array}{c}-2.175^{* *} \\
(0.992)\end{array}$ \\
\hline Deposit Ratio (DR) & $\begin{array}{l}-0.0322 \\
(0.0337)\end{array}$ & $\begin{array}{l}-0.0259 \\
(0.0408)\end{array}$ & $\begin{array}{c}-0.548^{* * *} \\
(0.167)\end{array}$ & $\begin{array}{l}-0.0417 \\
(0.0302)\end{array}$ & $\begin{array}{c}-0.437^{* * *} \\
(0.131)\end{array}$ & $\begin{array}{c}-0.243^{* * *} \\
(0.0829)\end{array}$ \\
\hline Yield & $\begin{array}{c}0.0224 \\
(0.0790)\end{array}$ & $\begin{array}{c}0.0879 \\
(0.0954)\end{array}$ & $\begin{array}{c}0.165^{*} \\
(0.0920)\end{array}$ & $\begin{array}{l}-0.0572 \\
(0.0776)\end{array}$ & $\begin{array}{c}-0.00898 \\
(0.0733)\end{array}$ & $\begin{array}{l}0.194^{* * * *} \\
(0.0690)\end{array}$ \\
\hline Post*Yield & $\begin{array}{c}-0.580^{* * *} \\
(0.267)\end{array}$ & $\begin{array}{c}-0.594^{* * *} \\
(0.266)\end{array}$ & $\begin{array}{c}-0.457^{* * * *} \\
(0.163)\end{array}$ & $\begin{array}{c}-0.311^{\text {*** }} \\
(0.115)\end{array}$ & $\begin{array}{l}-0.198^{* * *} \\
(0.0849)\end{array}$ & $\begin{array}{c}-0.178^{* * *} \\
(0.0652)\end{array}$ \\
\hline DR*Post & $\begin{array}{c}0.0771 \\
(0.0804)\end{array}$ & $\begin{array}{c}0.0792 \\
(0.0831)\end{array}$ & $\begin{array}{l}0.116^{* * * *} \\
(0.0406)\end{array}$ & $\begin{array}{c}0.0645 \\
(0.0504)\end{array}$ & $\begin{array}{c}0.0930^{* * * *} \\
(0.0318)\end{array}$ & $\begin{array}{l}0.0426^{* * *} \\
(0.0200)\end{array}$ \\
\hline DR*Yield & $\begin{array}{l}-0.00165 \\
(0.00151)\end{array}$ & $\begin{array}{c}-0.00306^{*} \\
(0.00184)\end{array}$ & $\begin{array}{c}-0.00390^{* * *} \\
(0.00172)\end{array}$ & $\begin{array}{l}0.000748 \\
(0.00182)\end{array}$ & $\begin{array}{c}-0.000659 \\
(0.00152)\end{array}$ & $\begin{array}{c}-0.00390^{* * * *} \\
(0.00142)\end{array}$ \\
\hline DR*Post*Yield & $\begin{array}{c}0.00895 \\
(0.00543)\end{array}$ & $\begin{array}{l}0.00947^{*} \\
(0.00538)\end{array}$ & $\begin{array}{l}0.00721^{\text {*** }} \\
(0.00332)\end{array}$ & $\begin{array}{l}0.00485^{*} \\
(0.00252)\end{array}$ & $\begin{array}{l}0.00315^{*} \\
(0.00185)\end{array}$ & $\begin{array}{l}0.00298^{* * *} \\
(0.00134)\end{array}$ \\
\hline Equity Ratio (ER) & $\begin{array}{l}-0.145 \\
(0.308)\end{array}$ & $\begin{array}{c}-0.0445 \\
(0.363)\end{array}$ & $\begin{array}{l}-5.407^{* * * *} \\
(1.601)\end{array}$ & $\begin{array}{l}-0.313 \\
(0.295)\end{array}$ & $\begin{array}{c}-4.337^{* * * *} \\
(1.266)\end{array}$ & $\begin{array}{c}-2.401^{* * * *} \\
(0.803)\end{array}$ \\
\hline ER*Yield & $\begin{array}{c}-0.00843 \\
(0.0175)\end{array}$ & $\begin{array}{l}-0.0222 \\
(0.0210)\end{array}$ & $\begin{array}{c}-0.0350^{*} \\
(0.0194)\end{array}$ & $\begin{array}{c}0.0117 \\
(0.0165)\end{array}$ & $\begin{array}{l}0.00380 \\
(0.0155)\end{array}$ & $\begin{array}{c}-0.0430^{* * * *} \\
(0.0155)\end{array}$ \\
\hline $\mathrm{ER} * \mathrm{DR}$ & $\begin{array}{c}0.00702 \\
(0.00716)\end{array}$ & $\begin{array}{c}0.00392 \\
(0.00892)\end{array}$ & $\begin{array}{l}0.108^{* * * *} \\
(0.0326)\end{array}$ & $\begin{array}{c}0.00923 \\
(0.00663)\end{array}$ & $\begin{array}{c}0.0862^{* * *} \\
(0.0257)\end{array}$ & $\begin{array}{c}0.0474^{* * *} \\
(0.0163)\end{array}$ \\
\hline ER*DR*Yield & $\begin{array}{c}0.000331 \\
(0.000339)\end{array}$ & $\begin{array}{c}0.000631 \\
(0.000412)\end{array}$ & $\begin{array}{l}0.000742^{* * *} \\
(0.000371)\end{array}$ & $\begin{array}{l}-7.13 \mathrm{e}-05 \\
(0.000343)\end{array}$ & $\begin{array}{c}7.55 \mathrm{e}-05 \\
(0.000318)\end{array}$ & $\begin{array}{c}0.000827^{* * * *} \\
(0.000302)\end{array}$ \\
\hline ER*DR*Post & $\begin{array}{l}-0.0102 \\
(0.0157)\end{array}$ & $\begin{array}{l}-0.0102 \\
(0.0168)\end{array}$ & $\begin{array}{l}-0.0197^{* * *} \\
(0.00757)\end{array}$ & $\begin{array}{c}-0.00902 \\
(0.0101)\end{array}$ & $\begin{array}{c}-0.0160^{* * *} \\
(0.00587)\end{array}$ & $\begin{array}{c}-0.00696^{*} \\
(0.00363)\end{array}$ \\
\hline ER*Post*Yield & $\begin{array}{l}0.102^{*} \\
(0.0527)\end{array}$ & $\begin{array}{l}0.107^{* *} \\
(0.0529)\end{array}$ & $\begin{array}{l}0.0862^{* *} \\
(0.0336)\end{array}$ & $\begin{array}{l}0.0532^{* *} \\
(0.0248)\end{array}$ & $\begin{array}{l}0.0338^{*} \\
(0.0193)\end{array}$ & $\begin{array}{l}0.0358^{* *} \\
(0.0139)\end{array}$ \\
\hline ER*DR*Post & $\begin{array}{l}-0.0102 \\
(0.0157)\end{array}$ & $\begin{array}{l}-0.0102 \\
(0.0168)\end{array}$ & $\begin{array}{l}-0.0197^{* *} \\
(0.00757)\end{array}$ & $\begin{array}{c}-0.00902 \\
(0.0101)\end{array}$ & $\begin{array}{c}-0.0160^{* * * *} \\
(0.00587)\end{array}$ & $\begin{array}{c}-0.00696^{*} \\
(0.00363)\end{array}$ \\
\hline ER*DR*Post*Yield & $\begin{array}{l}-0.00162 \\
(0.00107)\end{array}$ & $\begin{array}{l}-0.00175 \\
(0.00106)\end{array}$ & $\begin{array}{c}-0.00141^{* *} \\
(0.000670)\end{array}$ & $\begin{array}{c}-0.000855^{*} \\
(0.000512)\end{array}$ & $\begin{array}{l}-0.000536 \\
(0.000408)\end{array}$ & $\begin{array}{c}-0.000604 \\
(0.000269)\end{array}$ \\
\hline Observations & 402,649 & 402,649 & 402,649 & 386,551 & 386,551 & 353,771 \\
\hline$R^{2}$ & 0.052 & 0.064 & 0.234 & 0.475 & 0.588 & 0.864 \\
\hline Bank controls & No & Yes & Yes & Yes & Yes & Yes \\
\hline Bank FE & No & No & Yes & No & Yes & - \\
\hline Security FE & No & No & No & Yes & Yes & - \\
\hline Security*Bank FE & No & No & No & No & No & Yes \\
\hline
\end{tabular}

Notes: This table shows regressions on the security level (ISIN) for quarterly observations between Q4 2013 and Q4 2014. Compared to our benchmark specification these results are estimated by additionally interacting all coefficients with the Equity Ratio (in \%) of a bank. our benchmark specification these results are estimated by additionally interacting all coefficients with the Equity Ratio (in \%) of a bank.
The dependent variable Ln(Holdings) is calculated on nominal amounts and is determined by the holdings of security $i$ by bank $j$ at the end of quarter $t$. Post is the coefficient of a dummy variable that equals 1 from Q4 2014 onward (negative policy rates were announced in June 2014). Deposit Ratio is calculated as Customer Deposits over Total Assets (in \%). The Yield is the adjusted current yield (in \%) of a security. Standard errors are double clustered on the security and bank-time level. The Equity Ratio is computed as Equity divided by Total Assets (in $\%$ ). Bank controls include $\log$ (Total Assets). The different sets of fixed effects are marked with "Yes" if they are included in the regressions and "No" otherwise, additionally absorbed fixed effects are marked with "-". *** $p<0.01, * * p<0.05, * p<0.1$.

high-deposit banks invested more in higher-yielding securities with longer maturities compared to low deposit ratio banks. This is evidence of an additional channel of bank-risk taking that is consistent with our theoretical predictions in Section 1.1. Banks that are more affected by the introduction of negative policy rates take higher risks also by increasing the maturity of those securities in their portfolio that trade at higher yields. 
TABLE 7

Benchmark Model with Additional Interaction with Maturity

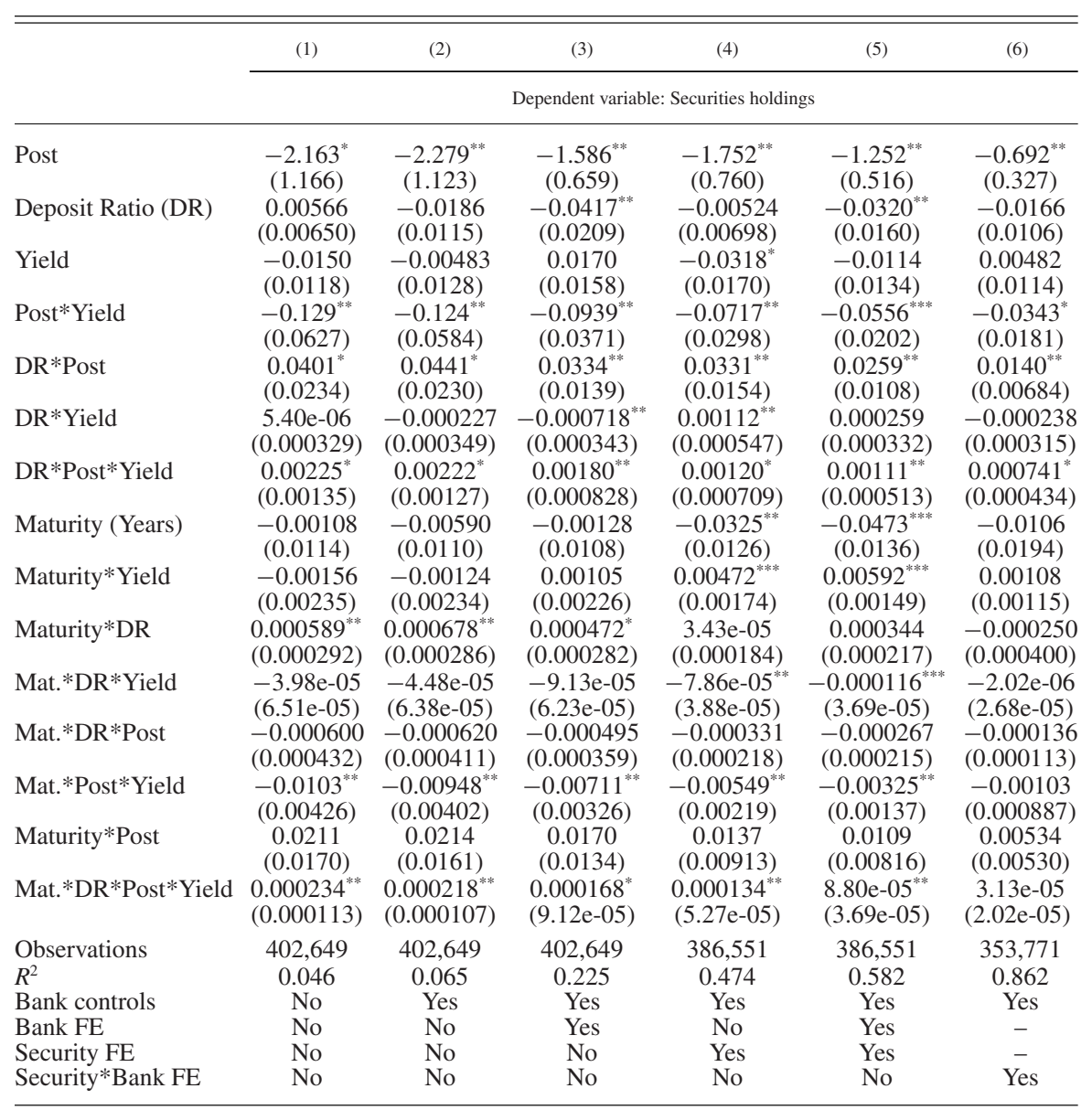

NotEs: This table shows regressions on the security level (ISIN) for quarterly observations between Q4 2013 and Q4 2014. Compared to our benchmark specification, these results are estimated by additionally interacting all coefficients with maturity in years of a security. The dependent variable Ln(Holdings) is calculated on nominal amounts and is determined by the holdings of security $i$ by bank $j$ at the end of quarter $t$. Post is the coefficient of a dummy variable that equals 1 from Q2 2014 onward (negative policy rates were announced in June 2014). Deposit Ratio is calculated as Customer Deposits over Total Assets (in \%). The Yield is the adjusted current yield (in \%) of a security. 2014). Deposit Ratio is calculated as Customer Deposits over Total Assets (in \%). The Yield is the adjusted current yield (in \%) of a security. Maturity is computed as the remaining maturity of a security in years and top-coded at 100 years. Standard errors are double clustered on the security and bank-time level. Bank controls include the Equity Ratio (computed as Equity/Total Assets) and $\log$ (Total Assets). The differen sets of fixed effects are marked with "Yes" if they are included in the regressions and "No" otherwise, additionally absorbed fixed effects are marked with "-". *** $p<0.01, * * p<0.05, * p<0.1$.

\subsection{The Lending Portfolio}

In the previous sections, we have analyzed the impact of negative policy rates on the securities holdings of large European banks. While securities are liquid assets and easier to rebalance in response to changes in policy rates, loans represent a larger fraction of banks' assets. We now provide some complementary evidence on the impact of negative rates on large banks' assets by using data on syndicated lending. 
Other studies that have addressed the impact of low or negative rates on banks' portfolios have mainly analyzed the loans' portfolios (see also discussion in section "Contribution and related literature"). High-deposit banks lend less, and to riskier firms in the euro area syndicated loan market (Heider, Saidi, and Schepens 2019). The negative effect on bank credit supply is however less pronounced when high-deposit banks also hold more excess reserves (Demiralp, Eisenschmidt, and Vlassopoulos 2017). Using credit register data for Italian banks, Bottero et al. (2019) find that affected banks rebalance their portfolios from liquid assets to lending, granting loans especially to ex ante riskier and smaller firms, without however higher ex post delinquencies-overall nonperforming loans do not change over the period.

Ideally, we would need detailed loan-level data for the banks in the sample (i.e., a credit register) in order to properly account for borrower risk. These data are not available at this level of granularity for banks headquartered in different countries and for the time period we are considering, while similar analysis can be carried out by using data of one country at the time (see, e.g., Bottero et al. 2019). We use syndicated loans transactions from Dealogic and include in the analysis only loans for which at least one of the banks in our sample was involved in the deal.

We run difference-in-differences regressions around the introduction of NPRs both at the bank-month level and at the bank-borrower level. For the first analysis, we construct the database as follows: We aggregate the volumes of all deals within a month at the level of a bank holding company, and include only banks with the role of "Mandated Arrangers." Because mandated arrangers "tend to hold on to their loan share throughout its life" (Heider, Saidi, and Schepens 2019), in this way we exclude possible effects arising from loan securitization. However, this selection significantly limits the size of our sample. Indeed, this specification includes just 60 bank-month observations for 15 banks in our sample for which the loan amount is reported (results from this subsample are reported in the first column of Table 8, under the heading "Aggregate Loans"). We also report the results of the analysis for a specification with allocated loan amounts (see column (2), "Aggregate Allocated Loans"). We divide the overall loan amount reported in Dealogic equally among all banks in the loan syndicate. This enables us to increase the sample size to 183 bank-month observations for 22 banks. For the analysis at the bank-borrower level, we include in the database single loans, considering banks in all roles, but including each bank only once. In this case, our sample consists of 568 bank-borrower observations for 22 banks.

Results are shown in Table 8. In our analysis at the bank-borrower level, we find some evidence that banks with a higher deposit ratio decrease the amounts of syndicated loans (see negative coefficient of Deposit Ratio*Post in column (3) of Table 8); however, this result is not robust across the different columns. Also, when we consider"Total Net Loans" in the bank-level analysis as reported in Table A3 we do not find a significant coefficient. Therefore, the evidence on overall lending is very weak. More related to the focus of our paper, to exploit differential risk-taking on the level 
TABLE 8

Evolution of The Syndicated Loan Portfolio

\begin{tabular}{|c|c|c|c|c|c|c|}
\hline & $\begin{array}{l}(1) \\
\text { Aggregate } \\
\text { loans }\end{array}$ & $\begin{array}{c}(2) \\
\text { Aggregate } \\
\text { allocated } \\
\text { loans }\end{array}$ & \multicolumn{4}{|c|}{ Individual loans } \\
\hline Rating & & & & & $\begin{array}{c}-0.192^{*} \\
(0.102)\end{array}$ & \\
\hline Post*Rating & & & & & $\begin{array}{c}-0.0366 \\
(0.136)\end{array}$ & \\
\hline Deposit Ratio*Post & $\begin{array}{l}-0.0236 \\
(0.0240)\end{array}$ & $\begin{array}{l}0.00602 \\
(0.0125)\end{array}$ & $\begin{array}{l}-0.0152^{*} \\
(0.00797)\end{array}$ & $\begin{array}{c}0.00270 \\
(0.00381)\end{array}$ & $\begin{array}{c}-0.0684^{* * *} \\
(0.0296)\end{array}$ & $\begin{array}{c}-0.0401^{*} \\
(0.0213)\end{array}$ \\
\hline Deposit Ratio*Rating & & & & & $\begin{array}{l}-0.00149 \\
(0.00219)\end{array}$ & $\begin{array}{l}-0.00203 \\
(0.00169)\end{array}$ \\
\hline Deposit Ratio*Post*Rating & & & & & $\begin{array}{l}0.00619^{* * *} \\
(0.00304)\end{array}$ & $\begin{array}{l}0.00406^{*} \\
(0.00223)\end{array}$ \\
\hline Observations & 60 & 183 & 568 & 530 & 125 & 123 \\
\hline$R^{2}$ & 0.508 & 0.606 & 0.197 & 0.920 & 0.744 & 0.906 \\
\hline Lead Arrangers only & Yes & Yes & No & No & No & No \\
\hline Bank-Month level & Yes & Yes & No & No & No & No \\
\hline Bank-Borrower level & No & No & Yes & Yes & Yes & Yes \\
\hline Bank FE & Yes & Yes & Yes & Yes & Yes & Yes \\
\hline Month FE & Yes & Yes & Yes & - & Yes & - \\
\hline Borrower-Month FE & No & No & No & Yes & No & Yes \\
\hline
\end{tabular}

NoTEs: This table shows regressions based on syndicated loan transactions obtained from Dealogic between November 1, 2013 and December 31,2014 . The dependent variable are aggregate loan amounts on the bank-month level in the first two columns and reported individual loa amounts on the bank or bank-borrower level in columns (3)-(6). The first two columns on the bank-month level include only "Lead Arrangers," columns (3)-(6) include loan shares of banks in all roles. Allocated amounts split the overall loan amount equally among banks if individual loan amounts are not reported. Post is the coefficient of a dummy variable that equals 1 from June 2014 onward. Deposit Ratio is calculated as Customer Deposits over Total Assets (in \%) in Q4 2013. Rating is a numerical variable ranging from 1 (AAA) to 16 (B-) and refers to rating reported in Dealogic. The different sets of fixed effects are marked with "Yes" if they are included in the regressions and "No" otherwise, additionally absorbed fixed effects are marked with "-". *** $p<0.01, * * p<0.05, * p<0.1$.

of the borrower, we include issuer ratings, ${ }^{29}$ in particular the interaction Deposit Ratio*Post*Rating. The coefficient of the triple interaction Deposit Ratio*Post*Rating is positive, thereby suggesting that banks more dependent on retail deposits increase their exposure to ex ante riskier borrowers relative to low deposit ratio banks (the coding of the rating variable is such that a higher value corresponds to a riskier rating). We find statistically significant results when restricting the sample to the period November 2013 to December 2014 in order to exclude the announcement of the ECB's asset purchases. ${ }^{30}$ These findings on loans and risk-taking are comparable to the positive triple interaction coefficient in our security-level regressions. While recognizing the caveats of the analysis due to severe sample limitations, these results provide suggestive evidence that high-deposit banks take higher risks after the introduction of negative policy rates also in their syndicated loan portfolios. More analysis on this topic based on granular data that may become available to researchers in the future is needed to provide further support to this result.

29. This restricts the analysis to loans where the rating of the borrower is specified, which further reduce the sample size. Ratings are coded with a numerical variable ranging from 1 for AAA to 16 for B-.

30. The coefficients of interest lose statistical significance in regressions based on an extended sample covering syndicated loan transactions during the years 2013-15. 


\section{CONCLUSIONS}

The implementation of negative policy rates in several countries in the last few years constituted an important novelty for policymakers and researchers interested in the effects of monetary policy. We contribute to the ongoing literature on this topic addressing the impact that negative rates have on financial intermediaries, in particular banks. We exploit a new data set covering the securities holdings of the 26 largest euro area banking groups and evaluate the impact of the introduction of negative policy rates on these portfolios. There was no previous evidence on the effects of negative policy rates on banks' risk-taking in securities despite the fact that securities holdings represent a large fraction of banks' assets and are important for policymakers with respect to risk-taking.

Our identification relies on a differential shock induced by negative rates on highand low-(retail) deposit banks. We find robust evidence that negative policy rates lead to reach-for-yield behavior in the securities holdings of more exposed banks. Comparing the period after the introduction of negative rates and before, banks more reliant ex ante on customer deposits (compared to the other banks) relatively increase their holdings of securities, with stronger effects for those securities yielding higher returns. Our analysis of portfolio choices within asset classes shows that the reachfor-yield effects are confined to holdings of debt securities issued by private firms, financial and nonfinancial. As regards to currency, the more affected banks reshuffle their holdings toward riskier securities denominated in USD, in addition to euro currency (this is relevant when considering international spillovers of euro area monetary policy). Moreover, we find that, after the introduction of NPR, the reach-for-yield effects for banks with higher customer deposits are stronger for weaker capitalized banks, thus consistent with risk-shifting behavior.

Our analysis complements the results obtained by other researchers which mainly focused on the impact of negative policy rates on the lending portfolio of banks. It remains to be investigated how the results of all these studies can be combined to assess the macro-economic impact of negative policy rates and to evaluate the possible trade-offs between temporary distortions in some parts of the financial sector and the effects on the economy at large. Our results also have important implications for the assessment of nonstandard monetary policy tools and how these tools can have a heterogeneous impact across financial intermediaries, that is not directly related to the primary objectives of policymakers. 


\section{APPENDIX A: ANNEX WITH ADDITIONAL FIGURES AND TABLES}

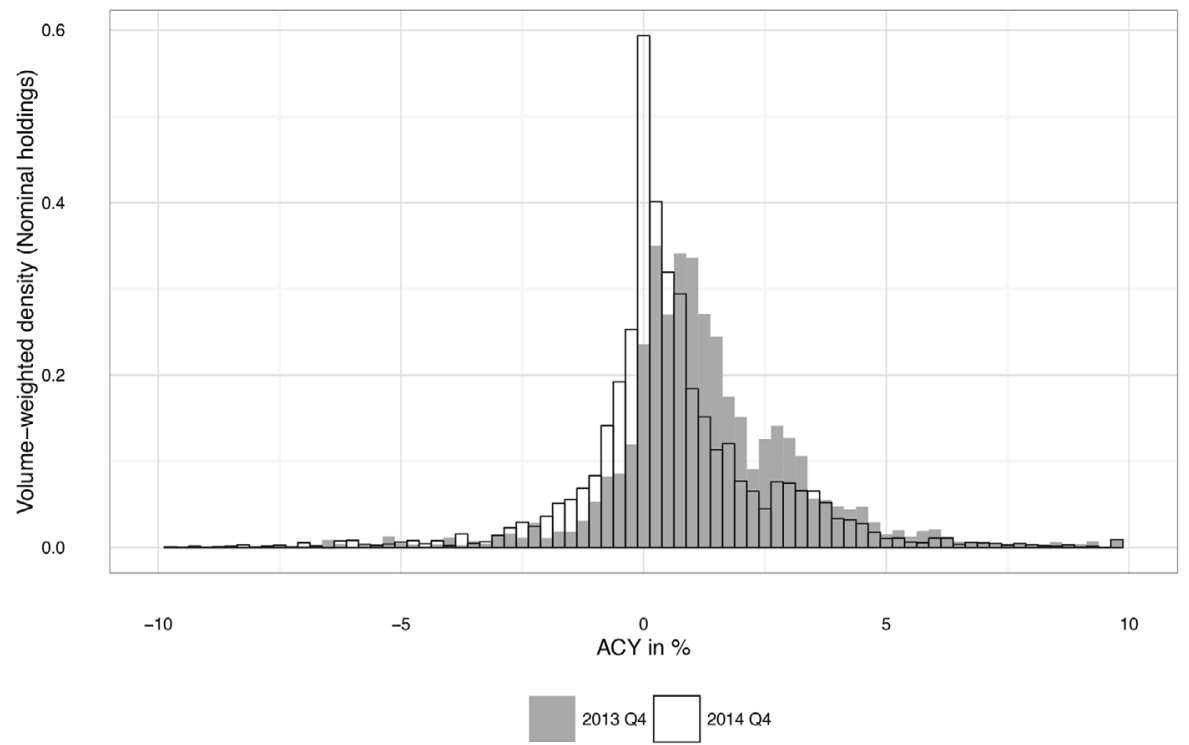

FIG A1. Distribution of the Yield (ACY) before and after Negative Policy Rates.

Notes: This figure shows a weighted histogram of the Yield (ACY, adjusted current yield) in \% of all securities at the beginning of our sample (2013 Q4) and at the end of our sample (2014 Q4). We use the nominal holdings of each security in the SHSG to determine the weights. 


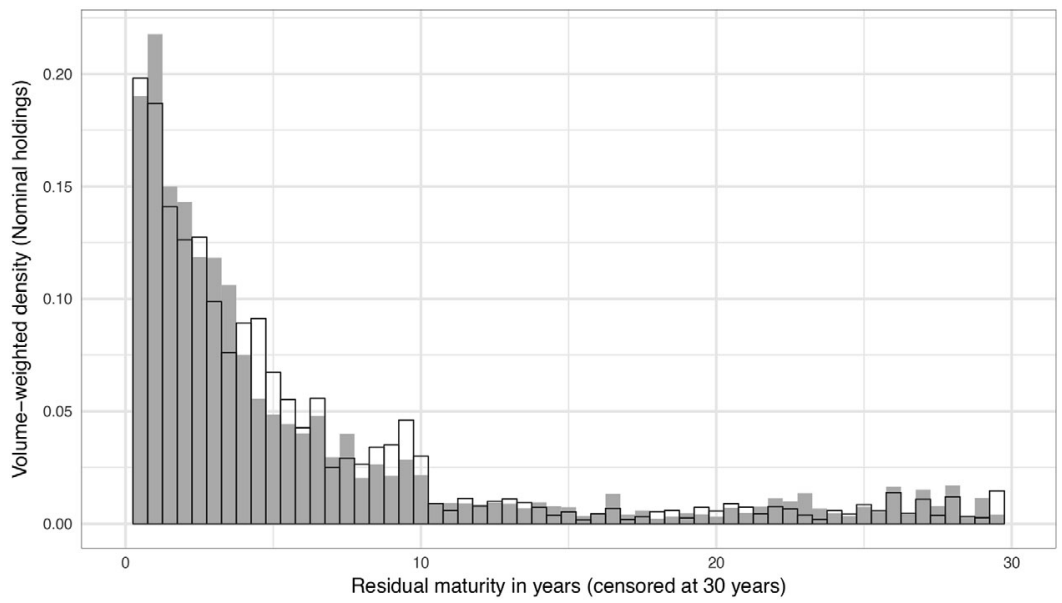

2013 Q4 2014 Q4

FIG A2. Distribution of Residual Maturity in Years before and after Negative Policy Rates.

Notes: This figure shows a weighted histogram of the residual maturity in years of all securities at the beginning of our sample (2013 Q4) and at the end of our sample (2014 Q4). We use the nominal holdings of each security in our sample to determine the weights.

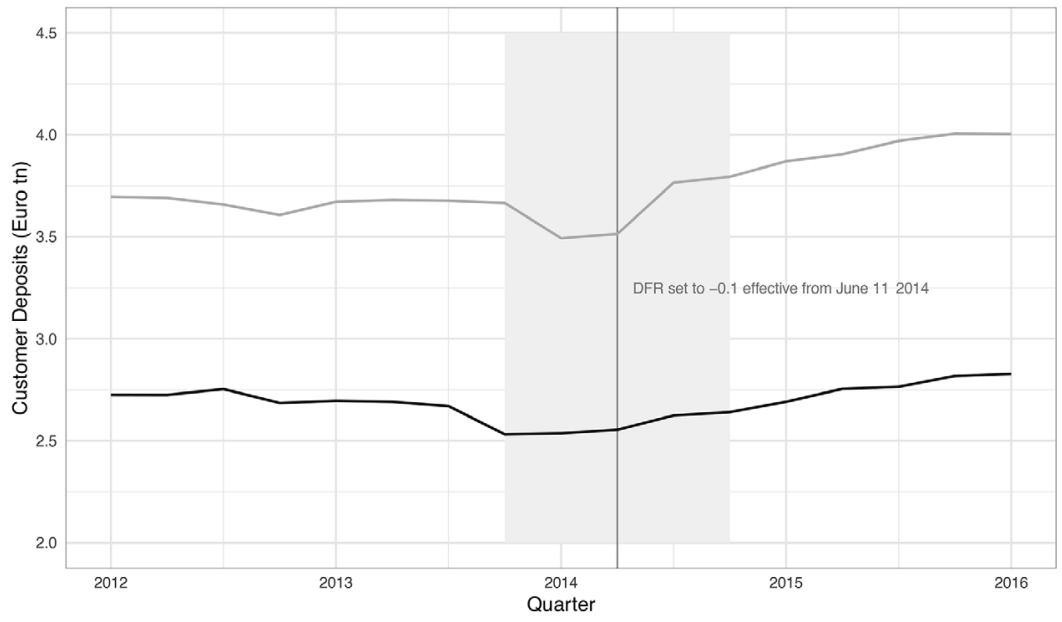

—_ Banks with above-median Deposit Ratio in 2013Q4 — Banks with below-median Deposit Ratio in 2013Q4

FIG A3. Total Amount of Customer Deposits over Time.

Notes: This figure shows a quarterly time series of Customer Deposits (in Euro trillion) between Q1 2012 and Q1 2016 obtained via SNL Financials. Banks are classified into above-median Deposit Ratio banks and below-median Deposit Ratio banks according to their Deposit Ratio in Q4 2013. The yellow line shows a quarterly total of Customer Deposits held at above-median Deposit Ratio banks. The blue line shows the quarterly total of Customer Deposits held at belowmedian Deposit Ratio banks. 


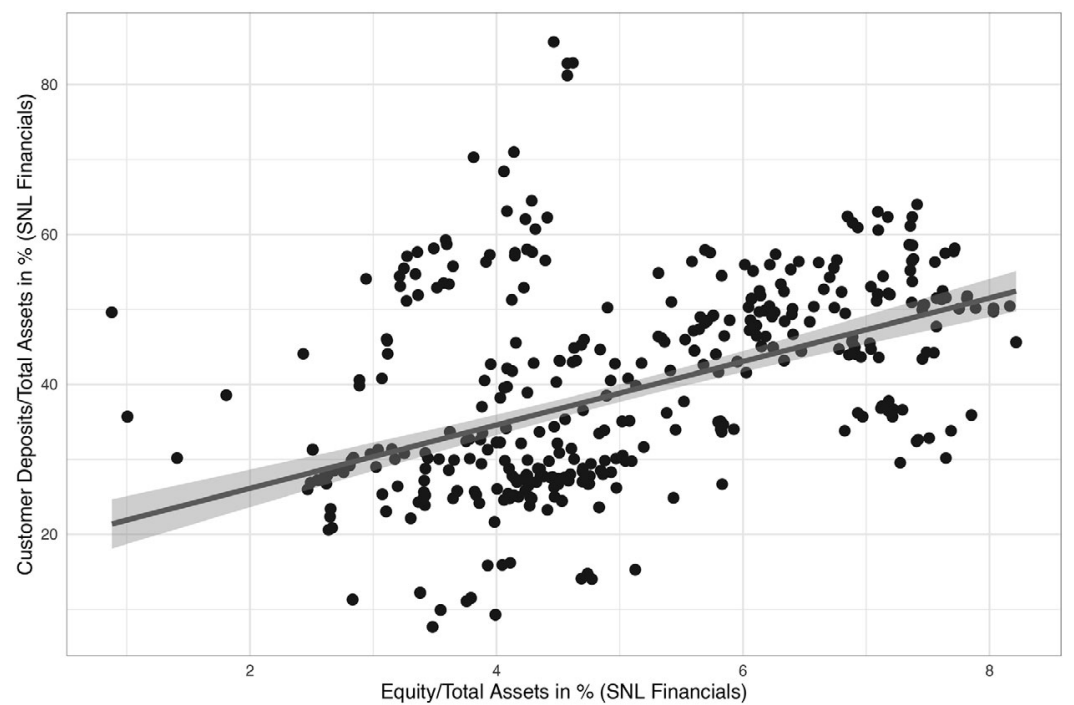

FIG A4. Equity Ratio and Deposit Ratio of the Banks in Our Sample.

Notes: This figure shows on the $x$-axis the ratio Equity/Total Assets (in \%) and on the $y$-axis the ratio of Customer Deposits/Total Assets (in \%). The quarterly observations between Q1 2012 and Q1 2016 are obtained from SNL Financials. The blue line is a fitted regression line illustrating the positive correlation between the two variables.

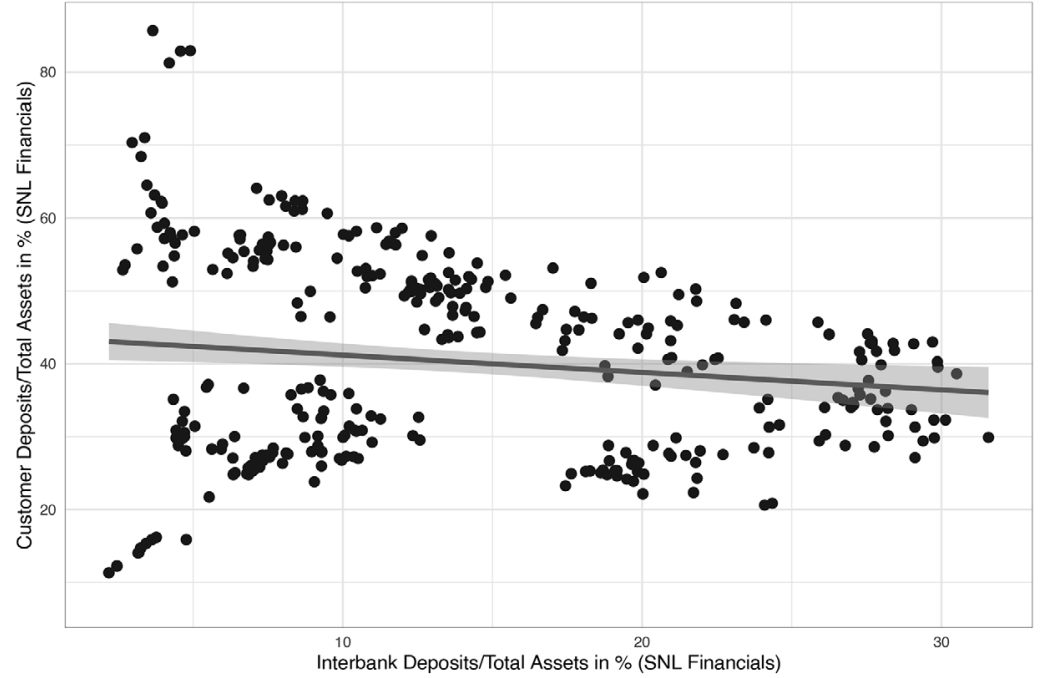

FIG A5. Interbank Deposits/TA and Deposit Ratio of the Banks in Our Sample.

Notes: This figure shows on the $x$-axis the ratio of Interbank Deposits/Total Assets (in \%) and on the $y$-axis the ratio of Customer Deposits/Total Assets (in \%). Interbank deposits are a proxy for wholesale deposits. The quarterly observations between Q1 2012 and Q1 2016 are obtained from SNL Financials. The blue line is a fitted regression line illustrating the negative correlation between the two variables. 
TABLE A1

List OF REPORTING BANKING GROUPS

\begin{tabular}{lllll}
\hline \hline & Country & \multicolumn{1}{c}{ Code } & Short name & \\
\hline $\mathbf{1}$ & AT & AT20100 & Erste & Eull name \\
$\mathbf{2}$ & BE & BE0403227515 & KBC & KBC Group Bank AG \\
$\mathbf{3}$ & BE & BE0403201185 & Belfius & Belfius \\
$\mathbf{4}$ & DE & DE00001 & DB & Deutsche Bank AG \\
$\mathbf{5}$ & DE & DE00003 & COBA & Commerzbank AG \\
$\mathbf{6}$ & DE & DE00316 & LBBW & Landesbank Baden-Wuerttemberg \\
$\mathbf{7}$ & DE & DE00317 & BLB & Bayerische Landesbank \\
$\mathbf{8}$ & DE & DE00319 & HELABA & Landesbank Hessen-Thóringen Girozentrale \\
$\mathbf{9}$ & DE & DE00320 & NORDLB & Norddeutsche Landesbank Girozentrale NORD/LB \\
$\mathbf{1 0}$ & DE & DE01121 & DZ & Deutsche Zentral-Genossenschaftsbank-DZ Bank AG \\
$\mathbf{1 1}$ & DE & DE03249 & PBB & Deutsche Pfandbriefbank AG \\
$\mathbf{1 2}$ & ES & ES0049 & BSCH & Banco Santander SA \\
$\mathbf{1 3}$ & ES & ES0182 & BBVA & Banco Bilbao Vizcaya Argentaria SA \\
$\mathbf{1 4}$ & ES & ES7865 & BFA & BFA Tenedora de Acciones SA (Bankia) \\
$\mathbf{1 5}$ & ES & ESHO486478 & La Caixa & Criteria Caixa Holding SA \\
$\mathbf{1 6}$ & FR & FR10278 & BFCM & Credit Mutuel CM5-CIC \\
$\mathbf{1 7}$ & FR & FR16188 & BPCE & Group BPCE \\
$\mathbf{1 8}$ & FR & FR30003 & SG & Société Générale \\
$\mathbf{1 9}$ & FR & FR30004 & BNP & BNP Paribas \\
$\mathbf{2 0}$ & FR & FR30006 & CA & Crédit Agricole Group-Crédit Agricole \\
$\mathbf{2 1}$ & IT & IT0000203426147 & MPdS & Banca Monte dei Paschi di Siena \\
$\mathbf{2 2}$ & IT & IT0000102484824 & UC & Unicredit SpA \\
$\mathbf{2 3}$ & IT & IT0000101262255 & ISP & Intesa Sanpaolo \\
$\mathbf{2 4}$ & NL & NL149 & ABN & ABN Amro Group NV \\
$\mathbf{2 5}$ & NL & NL163 & ING & ING Groep NV \\
$\mathbf{2 6}$ & NL & NL600 & Rabobank & Rabobank Group-Rabobank Nederland \\
& & & &
\end{tabular}

Notes: This table shows all banks included in the Securities Holdings Statistics by Banking Groups (SHSG) during the sample period (Q4 2013-Q4 2014). The column code displays RIAD/MFI codes of all banks in our sample.

TABLE A2

Robustness Checks of The Benchmark Regression

\begin{tabular}{|c|c|c|c|c|c|c|}
\hline \multirow[b]{4}{*}{ Post } & \multicolumn{2}{|c|}{ Weighted model } & \multicolumn{2}{|c|}{ Incl. zero holdings } & \multicolumn{2}{|c|}{ Portfolio controls } \\
\hline & (1) & (2) & (3) & (4) & & (6) \\
\hline & \multicolumn{2}{|c|}{ Securities Holdings } & \multicolumn{2}{|c|}{ Securities Holdings } & \multicolumn{2}{|c|}{ Securities Holdings } \\
\hline & $\begin{array}{c}-1.218^{* *} \\
(0.501)\end{array}$ & $\begin{array}{c}-0.678^{* *} \\
(0.312)\end{array}$ & $\begin{array}{c}-0.615^{* *} \\
(0.291)\end{array}$ & $\begin{array}{l}-0.209 \\
(0.163)\end{array}$ & $\begin{array}{c}-1.070^{* *} \\
(0.452)\end{array}$ & $\begin{array}{c}-0.546^{* *} \\
(0.264)\end{array}$ \\
\hline Deposit Ratio (DR) & $\begin{array}{c}-0.0316^{* *} \\
(0.0154)\end{array}$ & $\begin{array}{l}-0.0181^{*} \\
(0.00943)\end{array}$ & $\begin{array}{c}-0.0250^{* *} \\
(0.0111)\end{array}$ & $\begin{array}{c}-0.0163^{* *} \\
(0.00695)\end{array}$ & $\begin{array}{c}-0.0257^{*} \\
(0.0142)\end{array}$ & $\begin{array}{l}-0.0143^{*} \\
(0.00833)\end{array}$ \\
\hline Yield & $\begin{array}{c}-0.00112 \\
(0.0142)\end{array}$ & $\begin{array}{l}0.00861 \\
(0.0113)\end{array}$ & $\begin{array}{l}0.0283^{* *} \\
(0.0120)\end{array}$ & $\begin{array}{l}0.0387^{* *} \\
(0.0167)\end{array}$ & $\begin{array}{l}0.00471 \\
(0.0142)\end{array}$ & $\begin{array}{c}0.0194^{*} \\
(0.0102)\end{array}$ \\
\hline Post*Yield & $\begin{array}{c}-0.0623^{* * *} \\
(0.0207)\end{array}$ & $\begin{array}{c}-0.0335^{*} \\
(0.0178)\end{array}$ & $\begin{array}{c}-0.0774^{* * *} \\
(0.0257)\end{array}$ & $\begin{array}{c}-0.0539^{* *} \\
(0.0230)\end{array}$ & $\begin{array}{c}-0.0599^{* * * *} \\
(0.0191)\end{array}$ & $\begin{array}{c}-0.0382^{* * *} \\
(0.0157)\end{array}$ \\
\hline
\end{tabular}


TABLE A2

CONTINUED

\begin{tabular}{lccccccc}
\hline \hline & \multicolumn{2}{c}{ Weighted model } & \multicolumn{2}{c}{ Incl. zero holdings } & \multicolumn{2}{c}{ Portfolio controls } \\
& \multicolumn{2}{c}{$(1)$} & $(2)$ & $(3)$ & $(4)$ & $(5)$ & (6) \\
& \multicolumn{2}{c}{ Securities Holdings } & \multicolumn{2}{c}{ Securities Holdings } & \multicolumn{2}{c}{ Securities Holdings } \\
\hline DR*Post & $0.0253^{* *}$ & $0.0137^{* *}$ & $0.0143^{* *}$ & 0.00524 & $0.0217^{* *}$ & $0.0106^{*}$ \\
& $(0.0105)$ & $(0.00652)$ & $(0.00637)$ & $(0.00344)$ & $(0.00955)$ & $(0.00545)$ \\
DR*Yield & $2.80 \mathrm{e}-06$ & -0.000324 & -0.000143 & $-0.000704^{*}$ & $4.80 \mathrm{e}-05$ & $-0.000513^{*}$ \\
& $(0.000346)$ & $(0.000312)$ & $(0.000293)$ & $(0.000376)$ & $(0.000352)$ & $(0.000265)$ \\
DR*Post*Yield & $0.00132^{* *}$ & $0.000767^{*}$ & $0.00137^{* *}$ & $0.000997^{*}$ & $0.00112^{* *}$ & $0.000799^{* *}$ \\
& $(0.000549)$ & $(0.000426)$ & $(0.000557)$ & $(0.000520)$ & $(0.000473)$ & $(0.000358)$ \\
Observations & 386,551 & 353,771 & 737,823 & 704,303 & 386,551 & 353,771 \\
$R^{2}$ & 0.580 & 0.882 & 0.795 & 0.930 & 0.586 & 0.863 \\
Weighted model & Yes & Yes & No & No & No & No \\
Incl. zero holdings & No & No & Yes & Yes & No & No \\
Bank Portfolio controls & No & No & No & No & Yes & Yes \\
Bank controls & Yes & Yes & Yes & Yes & Yes & Yes \\
Bank FE & Yes & - & Yes & - & Yes & - \\
Security FE & Yes & - & Yes & - & Yes & - \\
Security*Bank FE & No & Yes & No & Yes & No & Yes \\
\hline
\end{tabular}

Notes: This table shows weighted regressions on the security level (ISIN) for quarterly observations between Q4 2013 and Q4 2014. For the weighted model in columns (1) and (2), we aggregate holdings by ISIN across all banks and use this variable as the weight of each security-quarter-bank observation. In columns (3) and (4), we add zero holdings and also include all very small holdings (below 0.5 million (5) w w overall nominal holdings across all banks). Columns (5) and (6) add two additional controls on the bank level: the fraction of public debt securities and the fraction of euro area securites in the securities portfolio of each bank. The specification is equivalent to our benchmark regression in Table 4. The dependent variable Ln(Holdings) is calculated on nominal amounts and is determined by the holdings of security by bank $j$ at the end of quarter $t$. Post is the coefficient of a dummy variable that equals 1 from Q2 2014 onward (negative policy rates were announced in June 2014). Deposit Ratio is calculated as Customer Deposits over Total Assets (in \%). The Yield is the adjusted current yield (in \%) of a security. Standard errors are clustered on the security and bank-time level. Bank controls include the Equity Ratio (computed as Equity/Total Assets) and $\log$ (Total Assets). The different sets of fixed effects are marked with "Yes" if they are included in the regression and "No" otherwise, additionally absorbed fixed effects are marked with " -". *** $p<0.01$, ** $p<0.05, * p<0.1$.

TABLE A3

Bank-Level Regressions on Deposits, Loans, and Noninterest Income

\begin{tabular}{lccc}
\hline \hline & $\begin{array}{c}(1) \\
\text { Ln(Customer } \\
\text { Deposits) }\end{array}$ & $\begin{array}{c}(2) \\
\text { Ln(Total Net } \\
\text { Loans) }\end{array}$ & $\begin{array}{c}(3) \\
\text { Ln(Noninterest } \\
\text { Income) }\end{array}$ \\
\hline Post & $-0.0417^{*}$ & -0.0444 & -0.135 \\
Deposit Ratio & $(0.0249)$ & $(0.0342)$ & $(0.377)$ \\
& 0.00470 & 0.00280 & 0.0111 \\
Deposit Ratio*Post & $(0.00412)$ & $(0.00440)$ & $(0.0113)$ \\
& $0.00155^{* *}$ & 0.00144 & 0.00300 \\
Observations & $(0.000727)$ & $(0.000926)$ & 73 \\
$R^{2}$ & 130 & 100 & 0.908 \\
FE & 0.998 & Bank & Bank \\
\hline
\end{tabular}

Notes: This table shows regressions at the bank level for quarterly observations between Q4 2013 and Q4 2014. Post is the coefficient of a dummy variable that equals 1 from Q2 2014 onward (negative policy rates were announced in June 2014). Deposit Ratio is calculated as Customer Deposits over Total Assets (in $\%$ ). All Data are obtained from SNL Financials. $* * * p<0.01, * * p<0.05$, $* p<0.1$. 


\section{LITERATURE CITED}

Abbassi, Puriya, Rajkamal Iyer, José-Luis Peydró, and Francesc R. Tous. (2016) "Securities Trading by Banks and Credit Supply: Micro-Evidence from the Crisis." Journal of Financial Economics, 121, 569-94.

Acharya, Viral V., and Sascha Steffen. (2015) "The 'greatest' carry trade ever? Understanding eurozone bank risks.” Journal of Financial Economics, 115, 215-36.

Altavilla, Carlo, Miguel Boucinha, and José-Luis Peydró. (2018) "Monetary Policy and Bank Profitability in a Low Interest Rate Environment.” Economic Policy, 33, 531-86.

Altavilla, Carlo, Lorenzo Burlon, Mariassunta Gianetti, and Sarah Holton. (2019) "Is There a Zero Lower Bound? The Effects of Negative Policy Rates on Banks and Firms." ECB Working Paper No. 2289.

Ampudia, Miguel, and Skander Van den Heuvel. (2018) "Monetary Policy and Bank Equity Values in a Time of Low Interest Rates.” ECB Working Paper No. 2199.

Arce, Oscar, Miguel Garcia-Posada, Sergio Mayordomo, and Steven R. G. Ongena. (2018) "Adapting Lending Policies When Negative Interest Rates Hit Banks' Profits." Banco de Espana Working Paper No. 1832.

Autor, David H. (2003) "Outsourcing at Will: The Contribution of Unjust Dismissal Doctrine to the Growth of Employment Outsourcing." Journal of Labor Economics, 21, 1-42.

Basten, Christoph, and Mike Mariathasan. (2018) "How Banks Respond to Negative Interest Rates: Evidence from the Swiss Exemption Threshold." CESifo Working Paper Series No. 6901.

Bernanke, Ben S. (2016) "Modifying the Fed's Policy Framework: Does a Higher Inflation Target Beat Negative Interest Rates?" Brookings. https://www.brookings.edu/blog/benbernanke/2016/09/13/modifying-the-feds-policy-framework-does-ahigher-inflationtarget-beat-negative-interest-rates/.

Bottero, Margherita, Camelia Minoiu, José-Luis Peydró, Andrea Polo, Andrea F. Presbitero, and Enrico Sette. (2019) "Negative Monetary Policy Rates and Portfolio Rebalancing: Evidence from Credit Register Data.” IMF Working Paper No. 19/44.

Boungou, Whelsy. (2020) “Negative Interest Rates Policy and Banks’ Risk-Taking: Empirical Evidence." Economics Letters, 186, 108760.

Brunnermeier, Markus K., Luis Garicano, Philip R. Lane, Marco Pagano, Ricardo Reis, Tano Santos, David Thesmar, Stijn Van Nieuwerburgh, and Dimitri Vayanos. (2016) "The Sovereign-Bank Diabolic Loop and ESBies." American Economic Review Papers \& Proceedings, 106, 508-12.

Brunnermeier, Markus K., and Yann Koby. (2018) “The Reversal Interest Rate.” NBER Working Paper No. 25406.

Choi, Jaewon, and Mathias Kronlund. (2017) "Reaching for Yield in Corporate Bond Mutual Funds." Review of Financial Studies, 31, 1930-65.

Dell'Ariccia, Giovanni, Luc Laeven, and Robert Marquez. (2014). "Real Interest Rates, Leverage, and Bank Risk-Taking." Journal of Economic Theory, 149, 65-99.

Dell'Ariccia, Giovanni, Luc Laeven, and Gustavo A. Suarez. (2017) “Bank Leverage and Monetary Policy's Risk-Taking Channel: Evidence from the United States.” Journal of Finance, 72, 613-54.

Demiralp, S., Jens Eisenschmidt, and Thomas Vlassopoulos. (2017) "Negative Interest Rates, Excess Liquidity and Bank Business Models: Banks' Reaction to Unconventional Monetary 
Policy in the Euro Area." Koç University-TUSIAD Economic Research Forum Working Paper 1708.

Di Maggio, Marco, and Marcin Kacperczyk. (2017) "The Unintended Consequences of the Zero Lower Bound Policy.” Journal of Financial Economics, 123, 59-80.

Eggertsson, Gauti, Ragnar Juelsrud, Lawrence Summers, and Ella Getz Wold. (2019) "Negative Nominal Interest Rates and the Bank Lending Channel." NBER Working Paper No. 25416.

Eisenschmidt, Jens, and Frank Smets. (2018) "Negative Interest Rates: Lessons from the Euro Area." Mimeo, presented at the XXI Annual Conference of the Central Bank of Chile.

English, William B., Skander J. Van den Heuvel, and Egon ZakrajŠek. (2018) "Interest Rate Risk and Bank Equity Valuations.” Journal of Monetary Economics, 98, 80-97.

Freixas, Xavier, and Jean-Charles Rochet. (2008) Microeconomics of Banking. Cambridge, MA: MIT Press.

Heider, Florian, Farzad Saidi, and Glenn Schepens. (2019) "Life below Zero: Bank Lending under Negative Policy Rates.” Review of Financial Studies, 32, 3728-61.

Koijen, Ralph S. J., Francois Koulischer, Benoot Nguyen, and Motohiro Yogo. (2018) "Quantitative Easing in the Euro Area: The Dynamics of Risk Exposures and the Impact on Asset Prices." Banque de France Working Paper No. 601.

Maddaloni, Angela, and Jose-Luis Peydró. (2011) "Bank Risk-Taking, Securitization, Supervision, and Low Interest Rates: Evidence from the Euro-Area and the U.S. Lending Standards." Review of Financial Studies, 24, 2121-65.

Morais, Bernardo, Josá-Luis Peydró, Jessica Roldán-Peña, and Claudia Ruiz-Ortega. (2019) "The International Bank Lending Channel of Monetary Policy Rates and QE: Credit Supply, Reach-for-Yield, and Real Effects." Journal of Finance, 74, 55-90.

Myers, Stewart C., and Raghuram G. Rajan. (1998) “The Paradox of Liquidity.” Quarterly Journal of Economics, 113, 733-71.

Nucera, Federico, Andró Lucas, Julia Schaumburg, and Bernd Schwaab. (2017) "Do Negative Interest Rates Make Banks Less Safe?" Economics Letters, 159, 112-15.

Obstfeld, Maurice. (2019) "Global Dimensions of U.S. Monetary Policy.” NBER Working Paper 26039.

Ozdagli, Ali K., and Zixuan (Kevin) Wang. (2019) "Interest Rates and Insurance Company Investment Behavior.” Working Paper.

Peydró, Jose-Luis, Andrea Polo, and Enrico Sette. (2017) "Monetary Policy at Work: Security and Credit Application Registers Evidence." CEPR Discussion Paper No. 12011.

Reghezza, Alessio, Jonathan Williams, Alessio Bongiovanni, and Riccardo Santamaria. (2019) "Do Negative Interest Rates Affect Bank Risk-Taking?" Bangor Business School Working Paper 19012.

Schelling, Tan, and Pascal Towbin. (2018) "Negative Interest Rates, Deposit Funding and Bank Lending." Mimeo.

Timmer, Yannick. (2018). "Cyclical investment behavior across financial institutions.” Journal of Financial Economics, 129, 268-86. 